\title{
Diabetes Associated Cognitive Decline, is there a Role for Exercise?
}

Cajsa Tonoli ${ }^{1,2}$, Elsa Heyman², Bart Roelands ${ }^{1,3}$, Luk Buyse ${ }^{1}$, Maria Francesca Piacentini' ${ }^{1,4}$, Serge Berthoin ${ }^{2}$ and Romain Meeusen ${ }^{1 *}$

${ }^{1}$ Department of Human Physiology and Sports Medicine, Vrije Universiteit Brussel, Belgium and UDSL

${ }^{2}$ EA4488, Activité Physique-Muscle-Santé, F-59000 Lille, France

${ }^{3} \mathrm{FWO}$ Fonds voor Wetenschappelijk Onderzoek Vlaanderen, Belgium

${ }^{4}$ Department Human Movement and Sports Science; University of Rome, Rome, Italy

\begin{abstract}
Type 1 Diabetes (T1D) can have a significant impact on brain structure and function. This so-called 'diabetesassociated cognitive decline' (DACD) can be attributed to diverse biochemical and neurochemical pathways which are caused by hyperglycaemia, hypoglycaemia, but also by c-peptide and insulin deficiency. Besides the positive effects of exercise on the acute and chronic glycaemic control in T1D patients, a growing number of studies also documented the beneficial influence of exercise on aspects of cognition and performance. Therefore, the purpose of the present narrative review is to discuss the associative aspects between a DACD and its' proposed mechanisms and the potential beneficial effect of exercise on a DACD.
\end{abstract}

\section{Introduction}

Type 1Diabetes (T1D) is characterized by chronic hyperglycaemia and the patient is therefore in need of insulin replacement therapy [1]. This is set on either a conventional or an intensive manner of treatment. Intensive insulin therapy (with 3 or more daily insulin injections) or continuous subcutaneous insulin infusion [2] is designed to achieve near-normal glucose control and minimizes the development and severity of diabetes associated complications. Because administration of exogenous insulin is required in both manners of insulin therapy, this can result in an alternation of hypoglycaemic and hyperglycaemic episodes [3]. Since glucose is the only energy for the brain, it is not inconceivable that the disruption of the glucose supply caused by hypoglycaemia and/or chronic hyperglycaemia might alter brain functioning. One example is the disturbance of the cognitive functions. Indeed, the effects of diabetes on the brain were already recognized by Miles and Roots in 1922 (cited in [4]). In 1965, Resko-Nielsen stated that the histological pattern observed in diabetes differs from that seen in any other clinical condition and therefore named it diabetic encephalopathy [5]. As different terms (e.g. cognitive dysfunction, cerebral impairment, central neuropathy) are used in literature, Mijnhout et al. [6] proposed a new term: 'diabetes-associated cognitive decline' (DACD), to include all terms and in that way facilitate research in this area [6]. This term is not suggestive of a particular pathogenesis, but merely describes a state of mild to moderate cognitive impairment [6].

The pathophysiological basis for a DACD remains poorly understood. In literature, episodes of hypoglycaemia $[7,8]$, hyperglycaemia $[9,10]$ and C-peptide/ insulin deficiencies [5,11-19] are mostly cited as harmful to the brain and would therefore be triggers for sustaining a DACD.

Exercise has been accepted and generally recommended for the management of T1D. Exercise increases aerobic fitness, reduces cardiovascular risk factors, and decreases body weight and body fat [20]. Physical activity (PA) improves or maintains chronic glycaemic control, a key trigger for DACD, by enhancing insulin sensitivity and stimulating muscle glucose uptake [21]. Therefore, exercise could be a preventive tool for chronic hyperglycaemia and hence presumably also for a DACD. Moreover, PA, especially aerobic exercise, has been shown to exert positive effects on the cognitive function in humans $[22,23]$. A meta-analysis of Colcombe \& Kramer [24] revealed a clear improvement in executive function due to exercise. Their meta-analysis showed that mental control, spatial memory tasks and psychomotor speed were also positively influenced by exercise compared to sedentary controls [24]. Although the role of exercise is clear, it is not that evident to discover which cognitive functions are altered in T1D, and which mechanisms are at the origin of the decreased cognitive function seen in T1D. Other specific questions that can be raised involve the importance of the different exercise intensities and durations on blood glucose levels, and the associated cognitive function in T1D patients. Therefore, in this paper we will review the existing literature on a DACD and the effects of exercise in T1D. Additionally, insights in the mechanisms through which a DACD is caused and how exercise could help will be suggested.

\section{Diabetes Associated Cognitive Decline}

To give a clear view on the affected cognitive domains in T1D, a screening of the literature on the electronic databases Pubmed and ISI Web of Knowledge was performed. Fifty-five original studies were found investigating a DACD in T1D patients (32 including adults, 23 including children).

Compared with non-diabetic children ( $<18$ years), T1D children showed significantly decreased performance on full Intelligence Quotient (IQ) and motor speed. No significant differences in cognitive function were found in verbal IQ, performance IQ, executive function, memory and motor function [26-42]. Adults on the other hand showed significantly lowered performance on the executive function, general IQ (full, verbal and performance IQ), spatial memory and motor speed[43-58] compared to non-diabetic adults.

Early onset disease (EOD) has been considered one of the

*Corresponding author: Romain Meeusen, Department of Human Physiology and Sports Medicine, Faculty of Physical Education and Physical Therapy, Vrije Universiteit Brussel, B-1050 Brussels, Belgium, Tel: (0032) 0262922 22; Fax: (0032) 0262928 76; E-mail: rmeeusen@vub.ac.be

Received May 15, 2013; Accepted June 29, 2013; Published July 05, 2013

Citation: Tonoli C, Heyman E, Roelands B, Buyse L, Piacentini MF, et al. (2013) Diabetes Associated Cognitive Decline, is there a Role for Exercise? J Diabetes Metab S10: 006. doi:10.4172/2155-6156.S10-006

Copyright: $\odot 2013$ Tonoli C, et al. This is an open-access article distributed under the terms of the Creative Commons Attribution License, which permits unrestricted use, distribution, and reproduction in any medium, provided the original author and source are credited. 
most prominent risk factors for sustaining a DACD [29,35,37,59]. Independently of diabetes duration, T1D children with an EOD show a significantly greater DACD for the following domains: verbal IQ, memory and executive function, and a moderate significant DACD for spatial memory. No studies were found comparing the DACD of T1D adults with an EOD versus a late onset disease (LOD). In brain imaging studies, results from magnetic resonance imaging (MRI) scans showed that an EOD was associated with higher rates of ventricular atrophy (61 vs. $20 \%)$ and higher rates of white matter lesions within the hippocampus (14 vs. 2\%) [60]. According to Ryan [60], brain volume correlates witha performance on cognitive tasks, providing strong support for the view that an EOD may affect normal brain development, and this leads to a DACD [60].

Intensive insulin therapy (with 3 or more daily insulin injections) or continuous subcutaneous insulin infusion [2] is designed to achieve near-normal glucose control, but also increases the risk of hypoglycaemic episodes. Four studies in adults [2,61-63] and 3 studies in children $[33,64,65]$ looked at the effects of different insulin therapies on cognitive function but did not find significant differences in any of the cognitive domains using different forms of medical management (either a conventional or an intensive manner of treatment).

Only two studies suggest that patients suffering from diabetic complications (retinopathy) performed significantly worse than controls (without diabetes) and T1D subjects without complications, especially on tasks that required sustained attention [44,66], spatial memory [44], hand-eye coordination [44], fluid intelligence [66], information processing [66] and concentration ability [66]. This might suggest that the brain can be affected through the same pathways as other diabetes associated complications, such as retinopathy, nephropathy, neuropathy and macrovascular complications.

\section{Mechanisms of a Diabetes Associated Cognitive Decline}

Literature describes 3 possible causes of a DACD: hypoglycaemic episodes, chronic hyperglycaemia and C-peptide/ insulin deficiencies (Figure 1).

\section{Hypoglycaemia}

The controversy still exists whether a DACD in T1D can be caused by hypoglycaemic episodes $[12,53]$. When blood glucose levels reach between 3.6-3.8 $\mathrm{mmol} / \mathrm{L}$, the release of counter-regulatory hormones (glucagon, adrenaline) starts. Blood glucose levels of 2.9-3.2 mmol/L provide autonomic and neuroglycopenic symptoms, while cognitive dysfunction starts at blood glucose levels of $<2.9 \mathrm{mmol} / \mathrm{L}$ [67]. However, during brain imaging studies, hypoglycaemic-associated changes were only seen when plasma glucose was lowered to $2.5 \mathrm{mmol} / \mathrm{L}$ [53] or 2.3 $\mathrm{mmol} / \mathrm{L}$ [68]. This might demonstrate the importance of episodes of severe hypoglycaemia.

In children differences in general IQ, memory (and spatial memory), executive function, motor function and motor speed in relation to a history of severe hypoglycaemic episodes were detected [26,28-31,6971]. In adults, the executive function and memory function were both significantly affected by severe hypoglycaemia $[53,55,58,72-80]$.

On the other hand, moderate episodes of hypoglycaemia might play a protective role against severe hypoglycaemia damages. In an animal study [81], rats were subjected to either 3 consecutive days of recurrent moderate $(1.4-2.2 \mathrm{mmol} / \mathrm{L})$ hypoglycaemia or saline injections. On the fourth day, rats were subjected to a hyperinsulinemic severe hypoglycaemic $(0.6 \mathrm{mmol} / \mathrm{L})$ clamp for 60 or $90 \mathrm{~min}$. In this study, antecedent recurrent moderate hypoglycaemia preconditioned the brain and markedly limited the extent of severe hypoglycaemiainduced neuronal damage and associated cognitive impairment [81].

The findings of the study of Auer et al. [7] suggests that despite the existence of an energy deficit during hypoglycaemia, there still might be a period which is resistant to hypoglycaemia-induced damage. The possibility exists that the brain uses alternative non-glucose fuels such as amino acids and ketone bodies, in order to maintain the cellular energy state for a limited period [82]. In a rat study, irreversible brain damage occurred only after a period of at least one hour of flat electroencephalogram (EEG), which might indicate that these alternative energy sources could act as a protective mechanism for brain damage.

Single episodes of (severe) hypoglycaemia might not be harmful since cognitive test performance returns to prehypoglycaemic baseline levels following restoration of the euglycaemic state [30,32]. Two studies $[30,32]$ show results in terms of number of hypoglycaemic episodes. They found a significant correlation between severe hypoglycaemia frequency ( 3 or more compared with 1 or 2 episodes) and a delay on spatial memory and timing in T1D children $[30,32]$.

How would hypoglycaemia be harmful for the brain?: Hypoglycaemia might cause neuronal necrosis through a neurochemical and biochemical pathway. At the neurochemical level, low blood glucose levels will alter ion pump activity and disturb cellular homeostasis $[7,8,83]$ which will cause an influx of calcium into the cells, creating an intracellular alkalosis. Increasing intracellular calcium is also thought to activate a number of proteolytic enzymes, which action may lead to mitochondrial damage and eventually cell death $[7,8,83]$. On the other hand, the decreased flux of glucose to the brain results in a fourfold increase in amino acid concentrations (mostly aspartate) [7], thereby activating neuronal necrosis [8]. In the biochemical pathway, the cell catabolizes proteins and deaminates amino acids which cause increased ammonia production. Ammonium, which is a strong base, powerfully increases the cellular $\mathrm{pH}$, resulting in an intense tissue alkalosis. Another reason for alkalosis might be lactate deficiency. Lactate tends to pull the tissue $\mathrm{pH}$ towards its own $\mathrm{pKa}$ (pKa of 3.83) [7]. However, due to a reduced production of lactate during hypoglycaemia, it is impossible to lower tissue $\mathrm{pH}$ which may reinforce alkalosis [7]. This alkalosis might explain why selective neuronal necrosis occurs during hypoglycaemia [7].

Alterations in cerebral vasoreactivity to hypoglycaemia and microvascular complications in T1D: Functional alterations in the cerebral vascular system - such as alterations in cerebral blood flow (CBF) have been associated with hypoglycaemic events in T1D. For

Mechanisms of Cognitive Decline in T1DM

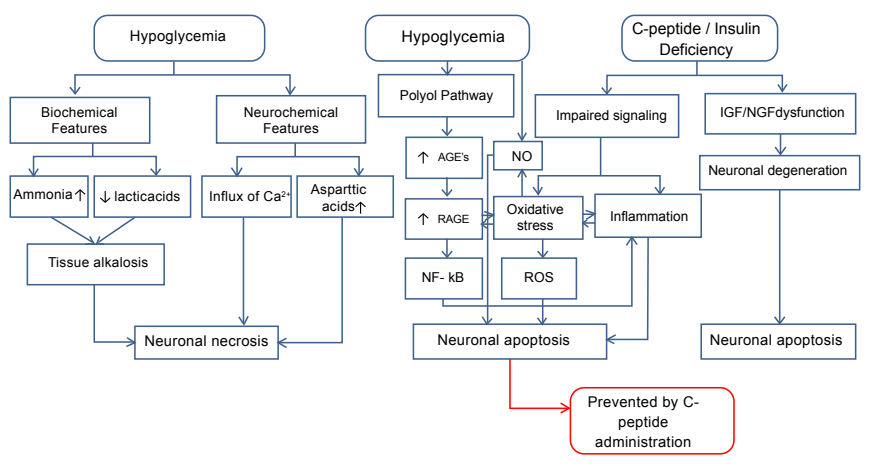

Figure 1: Mechanisms of a DACD. 
example, more severe hypoglycaemia was found to be significantly associated with a more pronounced decrease in brain volume and a decreased CBF [84]. According to Wessels et al. [85] vasoreactivity is an important compensatory mechanism in general, especially during hypoglycaemia. It is known that structural microvascular abnormalities include thickening of capillary basement membranes and cause reduced capillary density in diabetes [86], leading to decreased vasoreactivity.

A good vasoreactive response to hypoglycaemia is important in order to limit neuronal damage during hypoglycaemia [86]. Using MRI Wessels et al. [85] discovered that T1D patients with severe diabetic retinopathy (compared with patients without retinopathy) had decreased deactivation in the anterior cingulated gyrus and the orbitofrontal cortex during hypoglycaemia as compared with euglycaemia [85]. They attributed this to microvascular alterations causing regional abnormalities in the regulation of the CBF. In contrast, Tallroth et al. [87] found that CBF was increased when blood glucose levels were lower than $2.0 \mathrm{mmol} / \mathrm{L}$ and further increased until $15 \mathrm{~min}$ after normalization of blood glucose values. The increase in CBF was correlated with the rate of blood glucose decrease during initiation of hypoglycaemia. These results were supported by the studies of the research group of Macleod et al. [88,89].

Patients with microvascular complications are prone to thickening of the capillary basement membranes and a decreased number of capillaries, making them even more susceptible for alterations in cerebral vasoreactivity and subsequently have a bigger risk for sustaining a DACD. Consequently this can explain why patients suffering from diabetic complication(s) have a decreased performance at several cognitive domains compared to T1D subjects without complications $[44,66]$ and patients with microvascular complications have a significant smaller white matter (WM) volume than diabetic controls without microvascular complications [66].

\section{Hyperglycaemia}

Chronic hyperglycaemia (or poor glycaemic control) is another possible cause of a DACD. Poor glycaemic control was found to have negative effects on the memory function of T1D children $[27,64,65]$ and adults $[2,72]$. T1D patients with higher levels of glycated haemoglobin $\left(\mathrm{HbA}_{1 \mathrm{c}}\right)$ perform worse on motor speed and psychomotor efficiency [90]. It was shown by fMRI that higher levels of $\mathrm{HbA}_{1 c}$ are associated with lower activation in the right para-hippocampalgyrus and amygdala, while lower $\mathrm{HbA}_{1 c}$ levels resulted in hyperactivation of the brain [91].

How would hyperglycaemia be harmful for the brain?: There are several possible pathways to explain the interaction between high glucose levels and DACD. Hyperglycaemia causes oxidative stress via the polyol pathway, enhances the production of advanced glycation end products (AGEs), and increases vascular tone and permeability of the endothelial cell monolayer.

In the polyol pathway, the excess amount of glucose is converted to sorbitol, which oxidizes NADPH to NADP+ [9]. An increase in sorbitol has been linked to alterations in phosphoinositide and diacylglycerol metabolism. This, in combination with alterations in $\mathrm{Ca}^{2+}$, affects the protein kinases in the brain [9]. Sorbitol may also glycate nitrogens on proteins, called AGEs. The intermolecular collagen cross-linking caused by AGEs on extracellular matrix proteins and basement membrane components leads to diminished arterial and myocardial compliance and increased vascular stiffness [10]. Additionally, AGEs increase proinflammatory mechanisms by the activation of the receptor of AGE (RAGE) in the vessels, resulting in amplification and perpetuation of a loop for oxidative stress and the disregulation of proinflamatory cytokines [92]. The key target of RAGE is nuclear factor $\kappa \mathrm{B}$ (NF$\kappa \mathrm{B}$ ), both (RAGE and NF- $\kappa \mathrm{B}$ ) are up-regulated in the hippocampus of rats during hyperglycaemia. Up-regulation of RAGE and NF- $\kappa B$ is accompanied by an up-regulation of inflammatory factors such as TNF- $\alpha$, IL- $1 \beta$, IL-2, and IL-6 [18], consequently play a central role in the activation of inflammatory mechanisms [93]. These inflammatory factors can enhance oxidative stress and promote apoptotic stress [18]. This increase in oxidative stress leads also to AGE accumulation and creates thus an unremitting cycle [10]. Poor glycaemic control may thus lead to cellular and molecular damage and is therefore identified as a potential contributor to a DACD [93].

Increased oxidative stress is also associated with the activation of nitric oxide synthases (NOS) in the brain. Nitric Oxide (NO) has diverse biological activities including modulation of neurotransmission, promotion of synaptogenesis and synaptic remodelling, an involvement in long-term potentiation and depression, and is produced by the activity of NOS $[94,95]$. One of the negative effects is that the activation of NO causes ischemia, leading to neuronal apoptosis [94]. In ischemia, pro-inflammatory cytokines and leukocytes are activated [95].Restoration of blood flow to the ischemic area results in excessive production of reactive oxygen species (ROS) [95], what can result in significant damage to cell structures and even cell apoptosis. Therefore, we can assume that hyperglycaemia can induce, through different pathways, a DACD.

\section{C-peptide and insulin deficiencies}

C-peptide is a product of pro insulin cleavage, generated in pancreatic beta-cells as a part of normal insulin production. It is released into the bloodstream in equivalent amounts as insulin in response to various stimuli including elevated blood glucose. In patients with T1D, both insulin and C-peptide are decreased or absent. Insulin plays an important role in the regulation of brain metabolism and has a couple of neuroprotective effects such as preventing neuronal death during stroke and reducing neurological disability [96]. C-peptide has insulinomimetic effects by triggering the insulin receptor (IR) activity and increases glycogen synthesis and amino acid uptake, but has no glucose lowering effects [15]. In 4 months diabetic rats, there was a severe suppression of presynaptic synaptophysin and a marked decrease in presynaptic density. These deficits were fully prevented by the replacement of C-peptide [18]. Interestingly, Sima et al. [17] showed that c-peptide replacement prevented the up regulations of RAGE and NF- $\kappa$ B. Consequently, TNF- $\alpha$ as well as the pro- and antiinflammatory interleukins normalized in the hippocampus of diabetic $\mathrm{BB} /$ Wor rats [17].

The replacement of C-peptide also prevented the suppression of IGF-1, IGF receptor (IGF-IR), IR, NGF and NGF-Tra receptor in peripheral nerves of T1D animals. This resulted in the prevention of structural changes characterizing T1D polyneuropathy $[18,19]$. Li et al. [13] studied the possible preventive effects of C-peptide replacement on the early abnormalities in the expression of the IGF system in the central nervous system. C-peptide replaced animals showed a partial prevention of hippocampal neuronal loss which was associated with changes in apoptosis related proteins in the hippocampus [13]. These findings might suggest that IGF and insulin action provides antiapoptotic effects and are in line with earlier studies.

In summary, the data of several studies support the view that insulin/C peptide deficiency plays an important role in type 1 diabetesinduced neuronal apoptosis [12]. 


\section{Exercise in T1D: Short Term Episodes of Hypoglycaemia, Long Term Prevention of Chronic Hyperglycaemia?}

As described above, glycaemic control (prevention of episodes of hypoglycaemia and of chronic hyperglycaemia) is important in the prevention or treatment of a DACD. PA is generally recommended for its positive effects on glycaemic control, insulin sensitivity and stimulation of muscle glucose uptake $[97,98]$. Unfortunately, due to the complexity of regulating exogenous insulin in a physiologic manner during exercise, PA often results in episodes of hypoglycaemia or even episodes of hyperglycaemia shortly following or even long after completing exercise [99]. It is clear that the type of exercise will influence glycaemic control, possibly inducing or preventing periods of hyper- or hypoglycaemia.

While a large body of literature exists, full comparison across individual studies is largely qualitative and hampered by a wide range of study characteristics, which makes the interpretation of the current literature difficult. One also has to be aware that there is a large difference in acute exercise studies, where the effect of one single exercise bout on glycaemia is examined, and exercise training, in which a systematic exercise program is used. For the purpose of this article we defined acute exercise as 'exercise' while chronic exercise is defined as 'training'. Therefore, questions remain concerning the exact effect of training on glycaemic control in T1D. Subsequently, a screening of the literature resulted in a selection of 32 studies that provide more uniform results concerning the effects of different types of exercise on acute and chronic glycaemic control in T1D [100] (Figure 2).

\section{Changes in blood glucose levels after a single bout of exercise}

Glycaemia during exercise can vary inter- as well as intraindividually given that it depends on various factors such as exercise modality and intensity [101-103], nutritional status [104], time of insulin injection [105], or pre-exercise glycaemia level [106]. As expected, aerobic [97,107-111] and to a less important extent, acute high intensity exercise (HIE) [103,110,112-115] results in decreased levels of glucose in the T1D patient, which might cause an episode of hypoglycaemia during or after exercise. The effects of resistance training on acute glycaemia are currently unclear. Jimenez et al. [104] showed that insulin sensitivity remained unaffected after a single bout of resistance exercise, and therefore they suggest that resistance exercise may not cause as severe post-exercise hypoglycaemic episodes as aerobic exercise.

The blood glucose-lowering effect of moderate intensity aerobic exercise can increase the risk of developing an episode of hypoglycaemia during and after exercise. Exercise can acutely affect blood glucose levels, but also influence glycaemia the morning after and exercise bout, this is caused by a persistent increase of peripheral insulin sensitivity and to the required repletion of muscle glycogen stores, in which hepatic glucose production is unable to match the peripheral uptake of glucose by muscle. Consequently, late onset of hypoglycaemia can occur regardless of appropriate insulin reduction $[99,116]$. MacDonald et al. [114] followed 300 patients with T1D prospectively over 2 years. Sixteen percent developed late-onset (6-15 hours after vigorous exercise) hypoglycaemia. Besides this, previous exercise and the occurrence of previous hypoglycaemic episodes or poor glycaemic control, can affect the hypoglycaemic counter-regulatory mechanisms during subsequent exercise, which may cause even more episodes of severe hypoglycaemia [117]. In well controlled T1D patients with adequate insulinization, acute high intensity exercise may cause a less severe decrease of glucose levels during and after exercise or even prevent an episode of hyperglycemia due to an increase in catecholamines and sympathetic nervous system activation of hepatic glucose production which exceeds the rate of glucose use [117].

One way to prevent these exercise induced hypoglycaemic events is the ingestion of carbohydrates (CHO). West et al. [111] studied whether the ingestion of $75 \mathrm{~g}$ of $\mathrm{CHO} 30 \mathrm{~min}$ or $120 \mathrm{~min}$ before a 45 min running exercise (at $70 \%$ of their $\mathrm{VO}_{2 \max }$ ) could assure that blood levels stayed within acceptable ranges. They concluded that venous blood glucose levels decreased more when $\mathrm{CHO}$ was ingested 120 min before exercise compared to $30 \mathrm{~min}$ before exercise. Another manner to prevent these exercise-associated hypoglycaemic events is by performing an acute bout of high intensity sprint at the end of your moderate exercise. Indeed, studies found a smaller fall of blood glucose levels (or even an increase) due to an acute bout of HIE compared to an acute bout of aerobic exercise. This reaction can be attributed to a greater increase in catecholamines and growth hormone and hence in glucose hepatic production observed during the repeated bouts of HIE during moderate exercise [110,118]. Despite the fact that glucose utilization was greater and occurred faster in HIE + moderate vs. moderate exercise alone, the decrease in plasma glucose was smaller due to a much greater glucose production during HIE + moderate exercise [103,119]. Most recently, Iscoe and Riddell [115] compared moderate exercise with a HIE form with equivalent mechanical load in T1D adults. They showed that HIE provided better protection against nocturnal hypoglycemia. Rabasa-Lhoret et al. [101] observed that blood glucose levels decreased more in moderate continuous and/or longer exercise (periods ranging from 30 to $60 \mathrm{~min}$ and from 25 to $75 \%$ of $\mathrm{VO}_{2 \max }$ ) modes than in intense exercise forms. We could thus hypothesize that the use of high intensity bouts during a moderate form of exercise could successfully limit the risk of hypoglycaemia during and after exercise (Table 1).

\section{Changes in glycaemic control due to exercise training}

Twelve studies [120-131] examined the effects of aerobic training on chronic glycaemic control in T1D patients. Aerobic training results in a small, though significant, decrease in levels of $\mathrm{HbA}_{1 c}$ [100]. Aerobic exercise is known to enhance insulin action $24 \mathrm{~h}$ following [132] acute exercise. Therefore, it is recommended that exercise is performed frequently in order to maintain a constant increase in insulin sensitivity and thus improve $\mathrm{HbA}_{1 \mathrm{c}}$. Thus, training once a week might not be adequate to improve $\mathrm{HbA}_{1 \mathrm{c}}$ levels. For example, Huttunen et al. [133] performed an exercise intervention of 45 minutes, 1 time

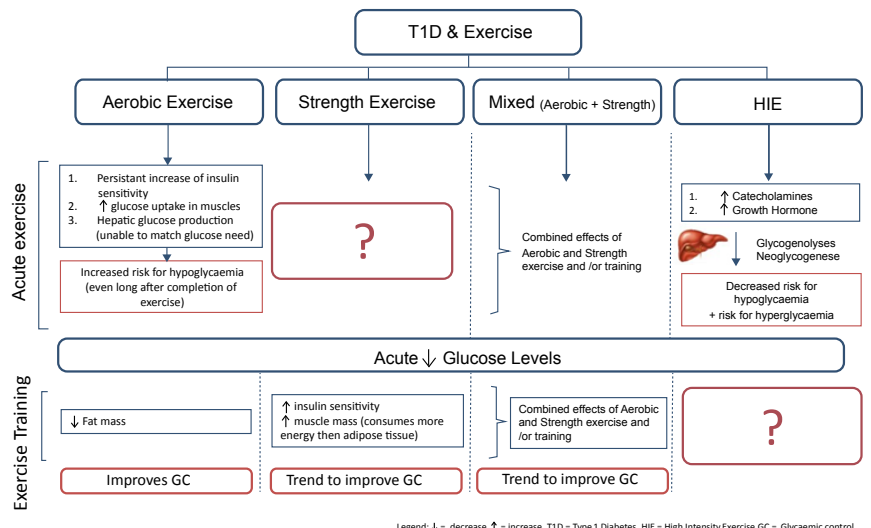

Figure 2: Effects of different types of exercise on acute and chronic glucose levels. 
Citation: Tonoli C, Heyman E, Roelands B, Buyse L, Piacentini MF, et al. (2013) Diabetes Associated Cognitive Decline, is there a Role for Exercise? J Diabetes Metab S10: 006. doi:10.4172/2155-6156.S10-006

Page 5 of 14

\begin{tabular}{|c|c|c|c|c|c|c|}
\hline \multirow[b]{2}{*}{ Reference } & \multirow{2}{*}{$\begin{array}{l}\text { No. of } \\
\text { Subjects } \\
\text { (males) }\end{array}$} & \multirow[b]{2}{*}{ Age (ys) } & \multicolumn{2}{|c|}{ Characteristics } & \multirow[t]{2}{*}{ Intervention } & \multirow[t]{2}{*}{ Outcome } \\
\hline & & & $\mathrm{HbA}_{1 \mathrm{c}}(\%)$ & $\begin{array}{l}\text { Insulin } \\
\text { doses/day }\end{array}$ & & \\
\hline $\begin{array}{l}\text { Heyman et al. } \\
2005[107]\end{array}$ & $\begin{array}{l}7 \text { T1D (7) } \\
7 \text { CG }\end{array}$ & $\begin{array}{l}10.5 \pm 0.3 \\
10.30 .3\end{array}$ & $7.7 \pm 0.7$ & $\begin{array}{l}0.92 \pm 0.2 \\
\mathrm{IU}^{\mathrm{kg}} \mathrm{kg}^{-1} \cdot \mathrm{day}^{-1}\end{array}$ & $\begin{array}{l}\text { Evaluating aerobic fitness during an incremental } \\
\text { maximal test and Aerobic power } \mathrm{PWC}_{170} \text { [IA- } \\
\text {,DA-]. [PP]. Exercise } \sim 2.25 \mathrm{~h} \text { after insulin } \\
\text { injection. }\end{array}$ & $\begin{array}{l}\text { T1D pre-pubertal boys } \\
\text { showed a significant } \downarrow \text { in blood glucose } \\
\text { during exercise. }\end{array}$ \\
\hline $\begin{array}{l}\text { Tansey et al. } \\
2006[108]\end{array}$ & 50 T1D (NA) & $14.8 \pm 1.7$ & $7.8 \pm 0.8$ & NA & $\begin{array}{l}1 \times 75 \mathrm{~min} \text { aerobic training session, heart rate } \\
140 \mathrm{bpm} .[\mathrm{IA}+, \mathrm{DA}+] .[\mathrm{PP}] .\end{array}$ & $\begin{array}{lc}- & 30 \% \text { of subjects became } \\
\text { hypoglycaemic } & \\
- & \text { Blood glucose level significant } \\
\downarrow & \end{array}$ \\
\hline $\begin{array}{l}\text { Heyman et al. } \\
2007[97]\end{array}$ & $\begin{array}{l}19 \text { T1D }(0) \\
19 \text { CG }\end{array}$ & $\begin{array}{l}15.9 \pm 0.3 \\
16.6 \pm 1.1\end{array}$ & $8.1 \pm 0.3$ & $\begin{array}{l}68.3 \pm 3.1 \\
\text { IU.day }{ }^{-1}\end{array}$ & $\begin{array}{l}\text { Maximal incremental exercise test on a bicycle } \\
\text { ergometer. [IA-,DA-]. [PP]. Exercise } \sim 2.25 \mathrm{~h} \\
\text { after insulin injection. }\end{array}$ & $\begin{array}{l}\text { T1D adolescents (girls) } \\
\text { showed a significant } \downarrow \text { in blood glucose } \\
\text { during exercise. }\end{array}$ \\
\hline $\begin{array}{l}\text { Poortmans et al. } \\
1986[109]\end{array}$ & $\begin{array}{l}17 \text { T1D (17) } \\
17 \text { CG (17) }\end{array}$ & $\begin{array}{l}16.2 \pm 0.7 \\
16.6 \pm 1.0\end{array}$ & $\begin{array}{l}\text { Good GC: } \\
7.3 \pm 0.3 \\
\text { Poor GC: } \\
11.4 \pm 0.9 \\
\text { Control: } \\
6.3 \pm 0.2\end{array}$ & NA & $\begin{array}{l}\text { Maximal incremental exercise on bicycle } \\
\text { ergometer. [IA-, DA-]. [PP]. }\end{array}$ & $\begin{array}{l}\text { - } \quad \text { Blood glucose levels } \\
\text { significant } \downarrow \text { more in well-controlled T1D } \\
\text { compared with poor controlled T1D. }\end{array}$ \\
\hline $\begin{array}{l}\text { Guelfi et al. } \\
2005 \text { [110] }\end{array}$ & 7 T1D (4) & $21.6 \pm 4$ & $7.4 \pm 1.5$ & $\begin{array}{l}14.8 \pm 7.5 \\
\text { IU.day }{ }^{-1}\end{array}$ & $\begin{array}{l}\text { A } 30-\text { min session of moderate continuous } \\
\text { training }\left(40 \% \text { of } \mathrm{VO}_{2 \text { max. }}\right) \text {. [IA -, DA-]. [PP]. }\end{array}$ & - $\quad$ Capillary glucose level \\
\hline $\begin{array}{l}\text { West et al. } 2011 \\
{[111]}\end{array}$ & 7 T1D (7) & $31 \pm 2$ & $8.3 \pm 0.1$ & NA & $\begin{array}{l}\text { Ingestion of } 75 \mathrm{~g} \mathrm{CHO} 30,60,90 \text { and } 120 \mathrm{~min} \\
\text { prior to a single session of } 45 \mathrm{~min} \text { of running } \\
\text { exercise }\left(70 \% \text { of } \mathrm{VO}_{2 \max }\right) \text {. [IA+,DA+]. [PP]. } \\
\text { Insulin injection } 30,60,90 \text { and } 120 \text { min prior to } \\
\text { the exercise. }\end{array}$ & $\begin{array}{l}\text { - } \quad 75 \mathrm{~g} \mathrm{CHO} 30 \text { min before } \\
\text { exercising decreases the incidence of } \\
\text { hypoglycemic episodes and augments } \\
\text { blood glucose levels after exercise } \\
\text { compared to the ingestion of } 75 \mathrm{~g} 60,90 \\
\text { or } 120 \text { minutes before exercise. }\end{array}$ \\
\hline $\begin{array}{l}\text { Yamanouchi et } \\
\text { al. } 2002[25]\end{array}$ & 6 T1D (3) & $42.7 \pm 13.6$ & $7.4 \pm 0.9$ & $\begin{array}{l}27.2 \pm 9.4 \\
\text { IU.day }{ }^{-1}\end{array}$ & $\begin{array}{l}30 \text { minutes of walking }\left(<50 \% \text { of their } \mathrm{VO}_{2 \max }\right) \\
\text { at a heart rate of } 90-110 \mathrm{bpm} \text {, before or after } \\
\text { breakfast. Subjects had } 1 \text { injection of regular } \\
\text { insulin } 30 \text { min before breakfast: exercise after } \\
\text { breakfast is performed while insulinaemia } \\
\text { is high (peak of rapid insulin) whereas the } \\
\text { exercise before breakfast is performed with low } \\
\text { insulinaemia. [IA/DA+]. [FS and PP]. Exercise } \\
1 \mathrm{~h} \text { after insulin injection. }\end{array}$ & $\begin{array}{l}\text { - Blood glucose values } \\
\text { significant } \downarrow \text { when exercise is performed } \\
\text { after breakfast, but not when exercise is } \\
\text { performed before breakfast. }\end{array}$ \\
\hline $\begin{array}{l}\text { Zinman et al. } \\
1977 \text { [119] }\end{array}$ & 16 T1D (10) & $30(22-43)$ & NA & NA & $\begin{array}{l}45 \text { min at } 50 \% \text { of } \mathrm{Vo}_{2 \text { max. }} \text { [IA infusion, DA NA] } 2 \\
\text { groups: } 1 \text { group continuous insulin infusion, } 1 \\
\text { group received one-third of usual intermediate } \\
\text { acting insulin by subcutaneous injection. [FS]. } \\
\text { Exercise } \sim 1 \mathrm{~h} \text { after insulin injection. }\end{array}$ & $\begin{array}{l}\text { - Rapid } \downarrow \text { in glucose in subjects } \\
\text { receiving one third of usual insulin. [P] } \\
\text { glucose during exercise is constant in } \\
\text { subjects with iv insulin infusion. }\end{array}$ \\
\hline $\begin{array}{l}\text { Zinman et al. } \\
1984 \text { [124] }\end{array}$ & 13 T1D (7) & $30.0 \pm 1.8$ & $\begin{array}{l}10.7 \pm 0.3 \\
\rightarrow 10.3 \pm \\
0.8\end{array}$ & $\begin{array}{l}37.6 \pm 3.2 \\
\text { IU.day }^{-1}\end{array}$ & $\begin{array}{l}\text { A } 45-\text { min session of aerobic exercise }(60-85 \% \text { of } \\
\left.\text { their } \mathrm{VO}_{2 \text { max }}\right) \text {. [IA-DA- (daily routines)]. [PAS, PP, } \\
\text { FS }=N A] \text {. Exercise } ~-45-135 \text { min after insulin } \\
\text { injection. }\end{array}$ & Plasma glucose significant $\downarrow$ \\
\hline
\end{tabular}

*Data presented as mean $\pm \mathrm{SD} ; \mathrm{N}^{\circ}$ of Subjects (males) = total number of subjects and the number between brackets are the number of males;

T1D: Type 1 Diabetes; GC: Glycaemic Control; NA: Not Applicable; CG: Controls; CHO: Carbohydrates; [VP]: Venous Plasma Glucose; [V]: Venous Whole blood, [P]: Plasma; [C]: Capillary; IA: Insulin Advice before/after Exercise; DA: Dietary Advice before/during or after Exercise; iv: intra-venous; $\downarrow$ : Decrease; [PAS]: Post Absorptive State (5-11h after last meal); [PP]: Post Prandial (during 4h after meal); [FS]: Fasting State ( $>12 \mathrm{~h}$ after meal); $\mathrm{HbA}_{1 \mathrm{c}}$ : Glycaeted Haemoglobin; VO ${ }_{2 \text { max }}$ : Maximal Oxygen Uptake; PWC: Physical Working Capacity

Table 1: Effects of a single bout of aerobic exercise on blood glucose levels in T1D patients (Table based on [100]).

per week during 12 weeks and $\mathrm{HbA}_{1 \mathrm{c}}$ levels were not affected by the intervention program. The duration of the training period is also an important influencing factor for decreasing $\mathrm{HbA}_{1 \mathrm{c}}$. $\mathrm{HbA}_{1 \mathrm{c}}$ levels decreased significantly only in training studies that lasted for more than 3 months. The frequency (times/week) of training will also influence the $\mathrm{HbA}_{1 \mathrm{c}}$ levels [100]. Besides this, baseline glycaemic control is also an important predictor of $\mathrm{HbA}_{1 c}$ improvement due to training. $\mathrm{HbA}_{1 c}$ decreases significantly more in T1D individuals with poor glycaemic $\left(>8 \% \mathrm{HbA}_{1 c}\right)$ control compared to individuals with good glycaemic control $\left(<8 \% \mathrm{HbA}_{1 \mathrm{c}}\right)$ [100]. Lehman et al. [134] demonstrated only a slight decrease in $\mathrm{HbA}_{1 \mathrm{c}}$ in well-controlled subjects who performed exercise training. This might suggest that exercise can be beneficial in order to improve glycaemic control particularly in poor-controlled T1D subjects.

Only 2studies [122,135] reported data on the effects of resistance training on glycaemic control. Aerobic training and resistance training have different actions in the body and can therefore influence glycaemic control through different pathways. Since fat mass decreases after a period of aerobic training [136], the change in the amount of body fat contributes to the change in insulin resistance over time in T1D patients[133]. On the other hand, resistance training enhances insulin sensitivity [137]. A meta-analysis of 9 randomized controlled trials evaluated 372 subjects with type 2 diabetes (T2D) [138]. When compared to not exercising, progressive resistance training led to a small but statistically significant absolute reduction of $0.3 \%$ in $\mathrm{HbA}_{1 \mathrm{c}}$, indicating that resistance training is a reasonable option in the management of glycaemic control in diabetic subjects [139]. This could be the result of obtaining greater muscle mass. At rest, skeletal muscle consumes $54.4 \mathrm{~kJ} / \mathrm{kg}(13.0 \mathrm{kcal} / \mathrm{kg})$ per day, which is larger than adipose tissue at $18.8 \mathrm{~kJ} / \mathrm{kg}(4.5 \mathrm{kcal} / \mathrm{kg})$ [140]. A greater muscle mass would thus consume more glucose and therefore could affect glycaemic control. 
The effects of aerobic training combined with resistance training were determined in 4 studies [141-144] using an adolescent population. There is still no consensus in literature on the combined effect of aerobic and resistance exercise. When comparing pre and post training status levels, there was only a slight decrease of HbAlc. However, the exercise group showed a significant decrease in $\mathrm{HbA}_{1 c}$ compared to the control T1D non-exercising group. A possible explanation is obviously the combination of both mechanisms of endurance and resistance training, as explained above $[133,140]$. The study of Heyman et al. [144] did not show a significant decrease of $\mathrm{HbA}_{1 \mathrm{c}}$ levels, while the study of Bernardini et al. [142] showed a large, significant decrease in $\mathrm{HbA}_{1 c}$. The contradictory results in literature might be partly explained by the types of interventions. For example, in the cross sectional study of Bernardini et al. [142], they defined 'combined training' as 'soccer, volleyball, tennis, basketball' across lifetime. Their improvement in glucose levels were probably not due to specific aerobic or resistance training programs, but due to the combined effects of different sports and their active lifestyle. In the study of Heyman et al. [144] adolescents only benefit from the training during the study period. This suggests that an active lifestyle (as measured in a cross sectional study) could reflect in good glycaemic control, whereas subjects with poor glycaemic control could be less motivated to engage in PA.

Only one training (7 weeks) study determined the effects of sprint training on glycaemic control [145]. The authors concluded that $\mathrm{HbA}_{1}$ levels were not influenced by long term High Intensity Training (HIT).

From the above studies, the following guidelines can be for the maintenance of improved chronic glycaemic control formulated: training (mostly aerobic) 3 months or more, training at least $2-3$ times a week and having dietary or insulin advice [100]. For example, West et al. [111] studied whether the ingestion of $75 \mathrm{~g}$ of $\mathrm{CHO} 30 \mathrm{~min}$ or $120 \mathrm{~min}$ before a $45 \mathrm{~min}$ running exercise ( $70 \%$ of their $\mathrm{VO}_{2 \max }$ ) could assure that blood levels stayed within acceptable ranges. They found that venous blood glucose levels decreased more when $\mathrm{CHO}$ was ingested $120 \mathrm{~min}$ before exercise compared to $30 \mathrm{~min}$ before exercise. Insulin levels on the other hand, should be adjusted in terms of intensity and duration of the exercise.

The relative difficulty of improving $\mathrm{HbA}_{1 c}$ with exercise training (all the more when patients do not benefit from specific advice about diet $\&$ insulin adaptations) might be partly caused by the difficulty for the patients to manage various important glycaemic variations depending on a large amount of factors (duration since the last meal or insulin dose, insulin absorption, initial glycaemia, hour of the day...). It could be difficult to adapt insulin and diet to these important day-today glycaemic variations, resulting in more hypoglycaemic episodes. In response, $\mathrm{T} 1 \mathrm{D}$ individuals can consume more $\mathrm{CHO}$ or reduce too much their insulin dose that in turn can induce slight hyperglycaemia and prevent improvement in $\mathrm{HbA}_{1 c}$ (Table 2).

\section{Exercising the Brain}

In the last two decades, both epidemiological and experimental studies were published with accumulating evidence supporting a positive relationship between exercise and cognitive function. Results from meta-analysis confirm significant positive effects of exercise on cognitive function $[146,147]$. The most convincing evidence of exercisemediated brain changes has been found in the hippocampus (a part in the brain involved in memory forming, organizing, and storing) [148]. In fact, studies show that exercise improves mostly cognitive functions such as tasks mediated by the hippocampus [149].
The exact mechanisms of the therapeutic effects of exercise remain unclear. Some hypotheses are suggested in literature to explain the possible therapeutic effects supporting the relationship between exercise and the brain, including supramolecular mechanisms (e.g. neurogenesis, synaptogenesis and angiogenesis) [150] and the neuroinflammatory processes [147].

\section{Supramolecular mechanisms}

Angiogenesis: Enhanced blood flow into the brain might be an effective approach to minimize or delay cognitive decline associated with aging [150]. Exercise enhances angiogenesis and vascular function in several regions, which might facilitate synaptic plasticity via multiple mechanisms [150-152]. These changes may lead to improved physiological functioning of the brain parenchyma [153]. For example, Insulin-Like Growth Factor (IGF-1) and Vascular Endothelial Growth Factor (VEGF), induce the formation of new blood vessels and are up-regulated after exercise [154]. Blockade of IGF-1 in the brain has also shown to prevent exercise-induced neuron proliferation in the dentategyrus [152]. Fabel et al. [155] showed that peripheral blockade of VEGF abolished running-induced neurogenesis but had no effect on baseline neurogenesis, suggesting VEGF is an important element of a somatic regulator of adult neurogenesis.

Synaptogenesis: There is growing evidence that Brain-derived Neurotrophic Factor (BDNF; a member of the neurotrophin family) has a strong modulatory function in synaptic plasticity. Indeed, BDNF induces neurogenesis (directly or through neurotransmitters) and neuroplasticity (such as pre and post-synaptic cascades that induce synaptogenesis) [156]. This includes memory formation (learning and behaviour, synaptic plasticity, synaptic efficacy and neuronal connectivity),promotion of the development of immature neurons and enhancement of adult neurons survival [156]. Decreased levels of BDNF have been related to various mental disorders such as depression, schizophrenia, Alzheimer's disease, dementia, Huntington's disease, Parkinson disease [157] and T2D [158,159] and are associated with an age-related decline in hippocampal volume and elevated memory deficits [160].

There is a growing body of evidence that aerobic exercise training increases serum [161,162] and plasma [163,164] BDNF levels. However, a couple of studies did not find an increase in serum or plasma BDNF levels due to aerobic training $[165,166]$ or strength training [166,167]. It seems that the effects of an endurance training program on (serum) BDNF levels differs from the effects of a single bout of endurance exercise on (serum) BDNF. In addition, Goekint et al. [167] cited that it is clear that an acute exercise bout will increase circulating BDNF levels, but that a longer training period not necessarily increases circulating BDNF concentrations. Furthermore, Ferris, et al. [168] reported that the magnitude of the increase in BDNF levels during exercise is related to exercise intensity. And thus, an increased release of BDNF into the blood circulation is a result of a physical stimulus in a dose-response manner [169]. It seems that only high intensity endurance exercises result into a significant increase of BDNF (Table 3).

Furthermore, exercise activates IGF-1 production, leading to angiogenesis (as described above) and presumably synaptogenesis through a downstream signalling cascade at the presynaptic and the postsynaptic level [150]. Ding et al. showed that blocking the IGF-I receptor significantly reversed an exercise-induced increase in the levels of BDNF mRNA, BDNF protein and pro-BDNF protein. This suggests that the effects of IGF-I may be partially accomplished by modulating the precursor to the mature BDNF. 
Citation: Tonoli C, Heyman E, Roelands B, Buyse L, Piacentini MF, et al. (2013) Diabetes Associated Cognitive Decline, is there a Role for Exercise? J Diabetes Metab S10: 006. doi:10.4172/2155-6156.S10-006

Page 7 of 14

\begin{tabular}{|c|c|c|c|c|c|c|}
\hline Reference & $\begin{array}{l}\text { No. of } \\
\text { Subjects } \\
\text { (males) }\end{array}$ & $\begin{array}{l}\text { Age } \\
\text { (ys) }\end{array}$ & $\begin{array}{l}\mathrm{HbA}_{1 \mathrm{c}}(\%) \\
\text { (pre/post) }\end{array}$ & $\begin{array}{l}\text { Insulin doses/ } \\
\text { day }\end{array}$ & Intervention & Outcome \\
\hline $\begin{array}{l}\text { Huttunen et al. } \\
1989[130]\end{array}$ & $\begin{array}{l}34(20) \\
16 \mathrm{EG} \\
16 \mathrm{CG}\end{array}$ & \begin{tabular}{l|}
11.9 \\
$(8-17)$
\end{tabular} & $\begin{array}{l}\text { EG: } 9.8 \pm \\
2.3 \rightarrow 10.5 \\
\pm 2.5 \\
\text { CG } 9.4 \pm 2.1 \rightarrow \\
9.7 \pm 2.2\end{array}$ & NA & $\begin{array}{l}45 \mathrm{~min}, 1 / \mathrm{wk}, 12 \mathrm{wks} \text {, aerobic exercise, } \\
\text { heart rate } 150 \mathrm{bpm} \text { (jogging, running, } \\
\text { gymnastics) vs. a non-training group. [IA/ } \\
\text { DA NA]. [PAS, PP, FS = NA]. }\end{array}$ & 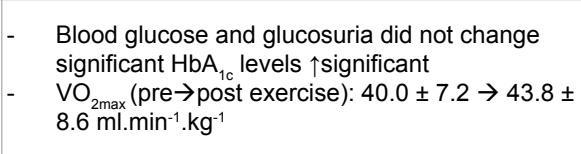 \\
\hline $\begin{array}{l}\text { Rowland et al. } \\
1985 \text { [131] }\end{array}$ & 14 T1D (7) & $9-14$ & $\begin{array}{l}9.9 \pm 1.4 \rightarrow \\
10.1 \pm 1.1\end{array}$ & NA & $\begin{array}{l}\text { 1h, 3/wk, } 12 \text { wk aerobic (running/walking) } \\
\text { exercise. [DA+, IA-]. [PAS, PP, FS = NA]. }\end{array}$ & $\begin{array}{ll}\text { - } & \mathrm{VO}_{2 \max } \uparrow \operatorname{sign}\left(38.4 \pm 4.6 \rightarrow 41.9 \pm 6.0 \mathrm{ml} \cdot \mathrm{min}^{-1} .\right. \\
& \left.\mathrm{kg}^{-1}\right) \\
\text { - } & \mathrm{HbA}_{1 \mathrm{c}}, \text { fasting blood glucose and glucosuria } \\
& (24 \mathrm{~h}) \text { did not change significant }\end{array}$ \\
\hline $\begin{array}{l}\text { Wong et al. } \\
2011[176]\end{array}$ & $\begin{array}{l}12 \text { EG (4) } \\
11 \text { CG (2) }\end{array}$ & $\begin{array}{l}12.3 \pm \\
2.07\end{array}$ & $\begin{array}{l}\text { CG: } 8.1 \pm 1.1 \\
E G: 8.2 \pm 1.4\end{array}$ & NA & $\begin{array}{l}12 \text { wks, } 3 \mathrm{~d} / \mathrm{wk} \text { aerobic }\left(40-60 \% \mathrm{VO}_{2 \max }\right) \\
30 \mathrm{~min} . \text { [IA/DA NA]. [PAS, PP, FS = NA]. }\end{array}$ & $\begin{array}{l}\text { - } \quad 9 \text { month } \mathrm{FU} \rightarrow \text { aerobic exercise group had } \\
\text { lower } \mathrm{HbA}_{1 \mathrm{c}} \text { levels than self-directed group. } \\
\text { - } \quad \text { No changes in } \mathrm{VO}_{2 \max }\end{array}$ \\
\hline $\begin{array}{l}\text { Bernardini et al. } \\
2004 \text { [142] }\end{array}$ & $\begin{array}{l}\text { 91 T1D } \\
(50)\end{array}$ & $\mid \begin{array}{l}14.8 \pm \\
2.7 \\
\end{array}$ & $\begin{array}{l}<60 \mathrm{~min} / \mathrm{wk}: \\
8.9 \pm 0.5 \\
120-360 \mathrm{~min} / \\
\text { wk: } \\
8.3 \pm 0.4 \\
360-480 \\
\text { min:wk: } \\
8.0 \pm 0.6\end{array}$ & NA & $\begin{array}{l}\text { Prospective cohort study: aerobic activity } \\
\text { defined as: walking, cycling, skating and } \\
\text { swimming during the last } 6 \text { months. [DA/ } \\
\text { IA NA]. [PAS, PP, FS = NA]. }\end{array}$ & $\begin{array}{l}\text { - Minutes of exercising is inversely correlated with } \\
\mathrm{HbA}_{1 \mathrm{c}} \text {. (60 min significant with } 120-360 \mathrm{~min} \text { and } \\
360-480 \mathrm{~min}) .\end{array}$ \\
\hline $\begin{array}{l}\text { Marrero et al. } \\
1988[125]\end{array}$ & 10 T1D (6) & $\begin{array}{l}13.3 \\
(12- \\
14)\end{array}$ & $\begin{array}{l}\text { Pre } \rightarrow \text { post : } \\
10.1 \pm 1.9 \rightarrow \\
9.2 \pm 2.2\end{array}$ & NA & $\begin{array}{l}\text { Non-supervised aerobic home exercise } \\
\text { protocol: } 45 \mathrm{~min}, 3 / \mathrm{wk}, 12 \text { wks (heart } \\
\text { rate } 160 \mathrm{bpm}) .[\mathrm{IA}-, \mathrm{DA}+] .[\mathrm{PAS}, \mathrm{PP}, \mathrm{FS} \\
=\mathrm{NA}] .\end{array}$ & $\begin{array}{ll}\text { - } & \mathrm{HbA}_{1 \mathrm{c}} \text { levels } \downarrow \text { significant } \\
\text { - } & \mathrm{VO}_{2 \mathrm{max}} \uparrow \text { significant }(40.4 \pm 8.8 \rightarrow 44.9 \pm 12.9 \\
& \left.\mathrm{ml} \cdot \mathrm{min}^{-1} \cdot \mathrm{kg}^{-1}\right)\end{array}$ \\
\hline $\begin{array}{l}\text { Michaliszyn et } \\
\text { al. } 2011[126]\end{array}$ & 12 T1D & $12-19$ & $\begin{array}{l}9.4 \pm 1.8 \rightarrow \\
9.4 \pm 2.0\end{array}$ & NA & $\begin{array}{l}60 \mathrm{~min}, 5 \text { day/wk, } 16 \mathrm{wk}(60-75 \% \text { of their } \\
\text { predicted peak heart rate) in a home } \\
\text { based program. [IA/DA NA]. }\end{array}$ & $\begin{array}{l}\mathrm{HBA}_{1 \mathrm{c}} \text { did not change significant No } \\
\text { measurement of } \mathrm{VO}_{2 \max }\end{array}$ \\
\hline $\begin{array}{l}\text { Ruzic et al. } \\
2007[127]\end{array}$ & $\begin{array}{l}20 \mathrm{~T} 1 \mathrm{D} \\
\text { (NA) }\end{array}$ & \begin{tabular}{l|}
12.8 \\
\pm 2.1 \\
$(9-16)$
\end{tabular} & $\begin{array}{l}\text { Pre } \rightarrow \text { post: } 8.3 \\
\pm 1.3 \rightarrow 7.9 \\
\pm 1.4\end{array}$ & $\begin{array}{l}3.6 \pm 0.6 \mathrm{IU}_{\mathrm{day}}{ }^{-1} \\
0.9 \pm 0.2 \mathrm{IU}_{\mathrm{kg}}{ }^{-1} \\
\text { day }^{-1}\end{array}$ & $\begin{array}{l}\text { High volume, low intensity program } \rightarrow 60 \\
\min ,<75 \% \text { of } \mathrm{HR}_{\max }, 2 \times 5 \text { days, } 3 x / \text { day, } \\
\text { exercise camp for children. [IA/DA-]. [PP] }\end{array}$ & $\begin{array}{ll}\text { - } & \mathrm{HbA}_{1 \mathrm{c}} \text { sign } \downarrow 10 \text { days after camp, but significant } \\
& \uparrow 2 \text { months after training } \\
\text { - } & \text { Blood glucose values } \downarrow \text { significant the last days } \\
\text { of training session } \\
\text { - } \quad \mathrm{No}_{2 \max } \text { levels were shown. }\end{array}$ \\
\hline $\begin{array}{l}\text { Sideraviciute et } \\
\text { al. } 2006 \text { [128] }\end{array}$ & 19 T1D (0) & $14-19$ & $\begin{array}{l}8.5 \pm 0.4 \rightarrow \\
7.8 \pm 0.3\end{array}$ & $\begin{array}{l}\text { Short term: } 26.4 \\
\pm 1.8 \text { IU.day } \\
1 \rightarrow 25.0 \pm 7.8 \\
I^{-} \text {day }^{-1}\end{array}$ & $\begin{array}{l}\text { Long term swim (aerobic) training: } 45 \\
\text { min, } 2 / w k, 14 \text { wks. [IA/DA NA]. [PAS, PP, } \\
\text { FS = NA]. }\end{array}$ & $\begin{array}{ll}\text { - } & \mathrm{HbA}_{1 \mathrm{c}} \downarrow \text { significant } \\
\text { - } & \text { Daily short acting insulin dose } \downarrow \text { significant after } \\
\text { exercise program. } & \mathrm{No} \mathrm{VO}_{2 \max } \text { levels were shown. }\end{array}$ \\
\hline $\begin{array}{l}\text { Laaksonen et } \\
\text { al. } 1999 \text { [120] }\end{array}$ & $\begin{array}{l}20 \mathrm{~T} 1 \mathrm{D} \\
(20)\end{array}$ & $\begin{array}{l}32 \pm \\
5.7\end{array}$ & $\begin{array}{l}\text { pre } \rightarrow \text { post: } 8.2 \\
\pm 1.1 \rightarrow 8.0 \\
\pm 1.0 \\
\text { CG } \rightarrow \text { EG: } 8.5 \\
\pm 1.6 \rightarrow 8.0 \\
\pm 1.0\end{array}$ & $\begin{array}{l}\text { Pre } \rightarrow \text { post } \\
\text { training: } 0.7 \pm \\
0.2 \rightarrow 0.7 \pm 0.2 \\
\text { IU. } \mathrm{kg}^{-1} \cdot \text { day }^{-1} \\
\\
\text { CG } \rightarrow \text { EG: } \\
0.7 \pm 0.2 \rightarrow 0.7 \pm \\
0.2 \mathrm{IU}_{\mathrm{kg}} \mathrm{kg}^{-1} \cdot \text { day }^{-1}\end{array}$ & $\begin{array}{l}1 \mathrm{wk}, 20-30 \mathrm{~min}, 50-60 \% \mathrm{VO}_{2 \text { peak }} \\
\text { gradually increased to } 12-16 \mathrm{wks}, 30- \\
60 \text { min, } 3-5 / \mathrm{wk}, 60-80 \% \mathrm{VO}_{2 \text { eak }} \text { aerobic } \\
\text { training program. [IA/DA NA]. [PAS, PP, } \\
\mathrm{FS}=\mathrm{NA}] .\end{array}$ & $\begin{array}{l}\text { - } \quad \mathrm{VO}_{2 \max } \text { significant } \uparrow \text { in training group }(43.4 \pm 8.0 \\
\left.\rightarrow 46.1 \pm 6.6 \mathrm{ml} \cdot \mathrm{min}^{-1} \cdot \mathrm{kg}^{-1}\right) \\
\text { - } \quad \mathrm{HbA}_{1 \mathrm{c}} \downarrow \text { with training and compared to control } \\
\text { group }\end{array}$ \\
\hline $\begin{array}{l}\text { Lehmann et al. } \\
1997[121]\end{array}$ & $\begin{array}{l}20 \mathrm{~T} 1 \mathrm{D} \\
(13)\end{array}$ & $\begin{array}{l}33 \pm \\
7.7 \\
(22- \\
48)\end{array}$ & $\begin{array}{l}7.6 \pm 4.4 \rightarrow \\
7.5 \pm 4.0\end{array}$ & $\begin{array}{l}48.4 \pm 15.1 \\
\rightarrow 40.4 \pm 13 \\
\text { IU.day }{ }^{-1}\end{array}$ & $\begin{array}{l}3 \times / w k, \text { min } 45 \text { min, } 3 \text { months of regular } \\
\text { endurance exercise,. } 50-70 \% \mathrm{VO}_{2 \max } \\
\text { [IA/DA NA]. [PAS, PP, FS = NA]. }\end{array}$ & $\begin{array}{ll}\text { - } & \text { Total insulin (IU/day) } \downarrow \text { significant } \\
\text { - } & \mathrm{HbA}_{1 \mathrm{c}} \text { did not } \downarrow \text { significant } \\
\text { - } & \mathrm{VO}_{2 \max } \text { increased significant }(2914 \pm 924 \rightarrow 3092 \\
& \pm 905 \mathrm{ml} / \mathrm{min}) .\end{array}$ \\
\hline $\begin{array}{l}\text { Ramalho et al. } \\
2006 \text { [122] }\end{array}$ & 7 T1D (2) & $\begin{array}{l}19.8 \pm \\
5.1\end{array}$ & $\begin{array}{l}8.7 \pm 1.6 \rightarrow \\
9.8 \pm 1.8\end{array}$ & $\begin{array}{l}0.95 \pm 0.3 \rightarrow 0.79 \\
\pm 0.3 \text { IU. } \mathrm{kg}^{-1} \cdot \text { day }^{-1}\end{array}$ & $\begin{array}{l}40 \text { min run or walk, first } 2 \text { wks: } 60-70 \% \\
\mathrm{HR}_{\max }, 3-6^{\text {th }} \text { week }=70-80 \% \mathrm{HR} \\
7-12^{\text {th }} \text { weeks }=70-90 \% \mathrm{HR}_{\max }, 3 / \text { wk, } 12 \\
\text { wks, aerobic training. }[\mathrm{IA}+, \mathrm{DA}+] .[\mathrm{PAS}, \\
\mathrm{PP}, \mathrm{FS}=\mathrm{NA}]\end{array}$ & 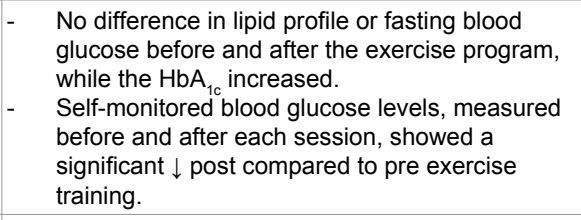 \\
\hline $\begin{array}{l}\text { Wallberg - } \\
\text { Henrikson, } \\
1986[123]\end{array}$ & $\begin{array}{l}6 \text { EG (NA) } \\
7 \text { CG (NA) }\end{array}$ & $\begin{array}{l}63 \pm 2 \\
35 \pm 2\end{array}$ & $\begin{array}{l}10.4 \pm 1.5 \\
10.6 \pm 1.6\end{array}$ & $\begin{array}{l}32 \pm 2 \text { IU.day }^{-1} \\
43 \pm 5 \text { IU.day }^{-1}\end{array}$ & $\begin{array}{l}20 \text { min of daily bicycle exercise during } \\
5 \text { months vs. non training. [IA/DA NA]. } \\
\text { [PAS, PP, FS = NA]. }\end{array}$ & $\begin{array}{l}\text { - } \quad \mathrm{VO}_{2 \max } \uparrow \text { significant }(\text { pre } \rightarrow \text { post training: } 30.2 \pm 2.1 \\
\rightarrow 32.7 \pm 2.1 \mathrm{ml}^{\mathrm{min}} \mathrm{mi}^{-1} \cdot \mathrm{kg}^{-1} \text { ) } \\
\text { - } \quad \mathrm{HbA}_{1 \mathrm{c}} \text { did not change significant after training }\end{array}$ \\
\hline $\begin{array}{l}\text { Zinman et al. } \\
1984 \text { [124] }\end{array}$ & $13 \mathrm{~T} 1 \mathrm{D}$ & $\begin{array}{l}30.0 \pm \\
1.8\end{array}$ & $\begin{array}{l}10.7 \pm 0.3 \rightarrow \\
10.3 \pm 0.8\end{array}$ & $\begin{array}{l}37.6 \pm 3.2 \\
\text { IU.day }^{-1}\end{array}$ & $\begin{array}{l}45 \text { min aerobic exercise, } 3 / \text { wk, } 12 \text { wks } \\
\left(60-85 \% \text { of their } \mathrm{VO}_{2 \text { max }}\right) \text {. [IA-DA- (daily } \\
\text { routines)]. Exercise } \sim 45-135 \text { min after } \\
\text { insulin injection. }\end{array}$ & $\begin{array}{ll}\text { - } & \mathrm{VO}_{2 \max } \text { increased sign }(33.8 \pm 1.7 \rightarrow 40.0 \pm 4.0 \\
& \left.\mathrm{ml}^{-1} \mathrm{~min}^{-1} \cdot \mathrm{kg}^{-1}\right) \\
\text { - } & {[\mathrm{P}] \mathrm{FGL} \text { and } \mathrm{HbA}_{1 \mathrm{c}} \text { did not significant change }}\end{array}$ \\
\hline
\end{tabular}

Data are presented as mean $\pm \mathrm{SD}$; No. of Subjects (males) = total number of subjects and the number between brackets are the number of males; [P]FGL: Fasting Glucose Levels; EG: Exercise Group; CG: Control Group; FU: Follow Up; T1D: Type 1 Diabetes; NA: Not Applicable; [VP]: Venous Plasma Glucose; [V]: Venous Whole blood; [P]: Plasma; [C]: Capillary; IA: Insulin Advice before/after Exercise; DA: Dietary Advice before/during or after Exercise; $\downarrow$ : Decrease; [PAS]: Post Absorptive State (5-11h after

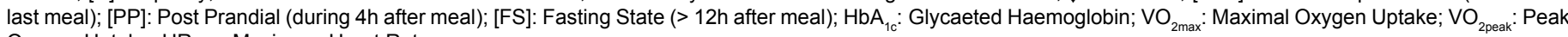
Oxygen Uptake; $\mathrm{HR}_{\max }$ : Maximum Heart Rate

Table 2: Effects of aerobic training on glycaemic control in T1D patients.(Table based on [100]). 
Citation: Tonoli C, Heyman E, Roelands B, Buyse L, Piacentini MF, et al. (2013) Diabetes Associated Cognitive Decline, is there a Role for Exercise? J Diabetes Metab S10: 006. doi:10.4172/2155-6156.S10-006

Page 8 of 14

A post-mortem study saw decreased expression of IGF-I in the hippocampus, cerebellum, pons and basal ganglia in two patients with EOD. This finding was associated with severe neuronal loss in the hippocampus and frontal cortex [92]. Li et al. [5,170] studied the possible role of hyperglycaemia vs. impaired insulin action on hippocampal apoptosis and neuronal loss in T1D rats. They found a decreased neuronal density in the hippocampus and a greater neuronal loss in T1D rats. These changes were preceded and accompanied by a significant $63 \%$ down-regulation of the hippocampal IGF system.

Neurogenesis: Many substances affect hippocampal neurogenesis. Increased cell genesis is associated with enhanced hippocampal synaptic plasticity and can be exercise-induced. The changes in synaptic plasticity occur in the same regions where neurogenesis was stimulated. This suggests that newborn cells play a functional role in neurogenesis due to exercise [147]. In particular, long-term potentiation -a physiological model of certain forms of learning and memory-is influenced by PA [147].

\section{Neuroinflammatory processes}

Another potential pathway through which the cognitive function may be influenced is the link between exercise and inflammation. For example, exercise increases the release of adrenaline, cortisol, growth hormone, and other factors that have immunomodulatory effects [171] and thus reduces the level of systemic inflammation. Furthermore, vigorous exercise leads to increased levels of proinflammatory cytokines (IL-1, IL-10, IL-6 and tumor necrosis factor-a $(\mathrm{TNF}-\alpha))[172,173]$, but simultaneously cytokine inhibitors and antiinflammatory cytokines restrict the magnitude and duration of the inflammatory response to exercise [149]. The release of cytokines such as vascular VEGF and Il-6 are associated with angiogenesis and may therefore contribute to the beneficial effects of exercise (Table 4 and 5).

\section{Diabetes-Associated Cognitive Decline, is there a Role for Exercise?}

Recently, strategies to fight or prevent the development of cognitive

\begin{tabular}{|c|c|c|c|c|c|c|}
\hline \multirow[b]{2}{*}{ Reference } & \multirow{2}{*}{$\begin{array}{l}\mathrm{N}^{\circ} \text { of } \\
\text { Subjects } \\
\text { (males) }\end{array}$} & \multirow{2}{*}{$\begin{array}{l}\text { Age } \\
\text { (ys) }\end{array}$} & \multicolumn{2}{|c|}{ Characteristics } & \multirow[t]{2}{*}{ Intervention } & \multirow[t]{2}{*}{ Outcome } \\
\hline & & & $\mathrm{HbA}_{1 \mathrm{c}}(\%)$ & $\begin{array}{l}\text { Insulin doses/ } \\
\text { day }\end{array}$ & & \\
\hline $\begin{array}{l}\text { Durak et al. } \\
1990[135]\end{array}$ & 8 T1D (8) & $31 \pm 3.5$ & $\begin{array}{l}6.9 \pm 1.4 \rightarrow \\
5.8 \pm 0.9\end{array}$ & $\begin{array}{l}46.2 \pm 15 \rightarrow 41.6 \\
\pm 16 \text { IU.day }^{-1}\end{array}$ & $\begin{array}{l}3 \mathrm{~d} / \mathrm{wk} ; 10 \text { wks, } 15 \text { exercises (max } 12 \text { reps), 3-6 } \\
\text { sets, rest intervals : } 30 \mathrm{~s}-2 \mathrm{~min} \text {. [IA/DA NA]. [PAS, } \\
\text { PP, FS = NA]. Exercise } \sim 5 \mathrm{~h} \text { after insulin injection. }\end{array}$ & - $\quad \mathrm{HbA}_{1 \mathrm{c}}$ and glucose levels $\downarrow$ significant \\
\hline $\begin{array}{l}\text { Ramalho et al. } \\
2006 \text { [122] }\end{array}$ & 6 T1D (1) & $\begin{array}{l}20.8 \pm \\
4.7\end{array}$ & $\begin{array}{l}8.2 \pm 2.9 \\
\rightarrow 7.6 \pm 1.6\end{array}$ & $\begin{array}{l}0.95 \pm 0.3 \rightarrow \\
0.79 \pm 0.28 \\
\text { IU.day }{ }^{-1}\end{array}$ & $\begin{array}{l}3 \mathrm{~d} / \mathrm{wk}, 12 \mathrm{wks}, 9 \text { exercises ( } 8-12 \text { reps), } 3 \text { sets. } \\
{[\mathrm{IA}+, \mathrm{DA}+] .}\end{array}$ & $\begin{array}{l}\text { - } \quad \text { No significant differences in parameters. } \\
\text { - Self-monitored blood glucose levels, } \\
\text { measured before and after each training } \\
\text { session, show non- significant } \uparrow\end{array}$ \\
\hline
\end{tabular}

Data are presented as mean \pm SD; No. of Subjects (males) $=$ total number of subjects and the number between brackets are the number of males; T1D: Type 1 Diabetes [VP]: Venous Plasma; [C]: Capillary; FGL: Fasting Glycaemic Level; IA: Insulin Advice before/after Exercise; DA: Dietary Advice before/during or after Exercise; $\downarrow$ : Decrease; [PAS]: Post Absorptive State (5-11 h after last meal); [PP]: Post Prandial (during 4h after meal); [FS]: Fasting State (> 12h after meal); HbA ${ }_{1 c}$ : Glycaeted Haemoglobin

Table 3: Effects of strength training on blood glucose levels in T1D patients.(Table based on [100]).

\begin{tabular}{|c|c|c|c|c|c|c|}
\hline \multirow[b]{2}{*}{ Reference } & \multirow{2}{*}{$\begin{array}{l}\text { No of } \\
\text { Subjects } \\
\text { (males) }\end{array}$} & \multirow{2}{*}{$\begin{array}{l}\text { Age } \\
\text { (ys) }\end{array}$} & \multicolumn{2}{|l|}{ Characteristics } & \multirow[t]{2}{*}{ Intervention } & \multirow[t]{2}{*}{ Outcome } \\
\hline & & & $\mathrm{HbA}_{1 \mathrm{c}}(\%)$ & $\begin{array}{l}\text { Insulin } \\
\text { doses/day }\end{array}$ & & \\
\hline $\begin{array}{l}\text { Bernardini } \\
\text { et al. } 2004 \\
{[142]}\end{array}$ & $90 \mathrm{~T} 1 \mathrm{D}$ & $\begin{array}{l}14.8 \pm \\
2.7\end{array}$ & $\begin{array}{l}60 \text { min exercise/ } \\
\text { wk: } 8.9 \pm 0.5 \\
\text { Mixed: } 7.4 \pm 0.6\end{array}$ & NA & $\begin{array}{l}\text { Prospective cohort study: aerobic activity defined } \\
\text { as: walking, cycling, skating and swimming. } \\
\text { Mixed defined as: soccer, volley- ball, tennis, } \\
\text { basketball. No intensity/quantity shown. [DA/IA } \\
\text { NA] }\end{array}$ & 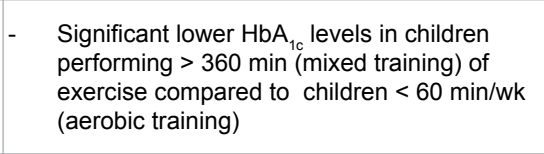 \\
\hline $\begin{array}{l}\text { D'Hooge et } \\
\text { al. } 2011[141]\end{array}$ & $\begin{array}{l}16 \text { T1D } \\
\text { (NA) } \\
8 \mathrm{EG} \\
8 \mathrm{CG}\end{array}$ & $\begin{array}{l}14.1 \\
(10- \\
18)\end{array}$ & $\begin{array}{l}\text { EG: } 7.9 \pm 1.3 \rightarrow \\
7.7 \pm 1.2 \\
\text { CG: } 8.7 \pm 0.8 \rightarrow \\
8.7 \pm 0.9\end{array}$ & $\begin{array}{l}0.96 \rightarrow 0.9 \\
\text { IU. } \mathrm{kg}^{-1} \cdot \text { day }^{-1}\end{array}$ & $\begin{array}{l}20 \text { wks, } 2 / \mathrm{wk}, 70 \mathrm{~min} \text {, aerobic and strength group. } \\
\text { Aerobic part: } 60-75 \% \text { of } \mathrm{HR}_{\text {peak }} \text {. Strength training: } \\
20 \mathrm{RM} \rightarrow 12 \mathrm{RM}, 3 \text { sets, } 10 \text { repetitions, } 60 \mathrm{sec} \\
\text { rest. [IA+, DA+]. [PAS, PP, FS = NA]. }\end{array}$ & $\begin{array}{ll}\text { - } & \text { EG: Capillary glucose significant } \downarrow \text { after } \\
\text { training, } \mathrm{HbA}_{1 \mathrm{c}} \text { not significant } \downarrow \\
\text { - } & \text { EG: Daily insulin doses: significant } \downarrow \\
\text { - } & \text { EG: VO }{ }_{2 \text { peak }} \downarrow \text { not significant }(1478 \rightarrow 1425 \\
& (\mathrm{mL} / \mathrm{min}))\end{array}$ \\
\hline $\begin{array}{l}\text { Heyman et al. } \\
2007[144]\end{array}$ & $\begin{array}{l}16 \text { T1D } \\
(0) \\
9=E G \\
7=C G\end{array}$ & $\begin{array}{l}\text { EG: } \\
15.9 \pm \\
0.5 \\
\text { CG: } \\
16.3 \pm \\
0.4\end{array}$ & $\begin{array}{l}\text { EG: } 7.3 \pm 0.9 \rightarrow \\
7.1 \pm 0.8 \\
\text { CG: } 8.5 \pm 1.3 \rightarrow \\
8.2 \pm 1.2\end{array}$ & $\begin{array}{l}\text { EG: } 1.0 \pm 0.1 \\
\text { U.kg }{ }^{-1} \cdot \text { day }^{-1} \\
\text { CG: } 1.1 \pm 0.1 \\
\text { U.kg } \\
-1 . \text { day }^{-1}\end{array}$ & $\begin{array}{l}22 \times 2 h+25 \times 1 \mathrm{~h} \text { of training during } 6 \text { months of } \\
\text { aerobic and strength training in adolescent girls. } \\
\text { [IA-,DA-]. [PAS, PP, FS = NA]. }\end{array}$ & $\begin{array}{ll}\text { - } & \text { Insulin dose per day } \downarrow \text { exercise group } \\
- & \text { HbA1c } \downarrow \text { not significant in } E G \text { compared with } \\
\text { CG } & \\
\text { - } & \text { [P]FGL were significant } \downarrow \text { in EG compared } \\
\text { - } & \text { with CG. } \\
\text { PWC }_{170} \text { was not significant } \uparrow \text { in watts } / \mathrm{kg} .\end{array}$ \\
\hline $\begin{array}{l}\text { Mosher et al. } \\
1998[142]\end{array}$ & $\begin{array}{l}10 \mathrm{~T} 1 \mathrm{D} \\
(10) \\
11 \mathrm{CG}\end{array}$ & $17.2 \pm$ & $\begin{array}{l}\text { Pre }- \text { Post EG : } \\
7.72 \pm 1.26 \rightarrow \\
6.76 \pm 1.07 \\
\text { CG vs. EG: } 4.47 \\
\pm 0.6 \text { vs. } 6.76 \pm \\
1.07\end{array}$ & $\begin{array}{l}1.02 \pm 0.12 \\
\text { IU. } \mathrm{kg}^{-1} \cdot \mathrm{day}^{-1}\end{array}$ & $\begin{array}{l}45 \text { min, 3/wk; } 12 \text { wks. Aerobic circuit training + } \\
\text { strength training. [IA-/DA NA]. [PAS, PP, FS = } \\
\text { NA]. }\end{array}$ & $\begin{array}{ll}\text { - } & \text { HbA1c } \downarrow \text { significant } \\
\text { - } & \text { FGL plasma was unchanged }\end{array}$ \\
\hline
\end{tabular}

${ }^{*}$ Data presented as mean $\pm \mathrm{SD} ; \mathrm{N}^{\circ}$ of Subjects (males) = total number of subjects and the number between brackets are the number of males; $[\mathrm{P}] \mathrm{FGL}=$ fasting glucose levels; EG = exercise group; CG = control Group; T1D = Type 1 Diabetes; NA = not applicable; [VP]: Venous Plasma Glucose; [V]: Venous Whole blood[P]: Plasma; [C]: Capillary; IA: Insulin Advice before/after Exercise; DA: Dietary Advice before/during or after Exercise; $\downarrow$ : Decrease; [PAS]: Post Absorptive State (5-11h after last meal); [PP]: Post Prandial (during 4h after meal); [FS]: Fasting State ( $>12 \mathrm{~h}$ after meal); $\mathrm{HbA}_{1 \mathrm{c}}$ : Glycaeted Haemoglobin; $\mathrm{VO}_{2 \text { max }}:$ Maximal Oxygen Uptake; VO $_{2 \text { peak }}$ : Peak Oxygen Uptake; $\mathrm{HR}_{\text {peak }}$ : Heart Rate Peak

Table 4: Effects of combined (aerobic and strength) training program on glycaemic control in T1D patients.(Table based on [100]). 
Citation: Tonoli C, Heyman E, Roelands B, Buyse L, Piacentini MF, et al. (2013) Diabetes Associated Cognitive Decline, is there a Role for Exercise? J Diabetes Metab S10: 006. doi:10.4172/2155-6156.S10-006

Page 9 of 14

\begin{tabular}{|c|c|c|c|c|c|c|}
\hline \multirow[b]{2}{*}{ Reference } & \multirow{2}{*}{$\begin{array}{l}\text { No. of } \\
\text { Subjects } \\
\text { (males) }\end{array}$} & \multirow[b]{2}{*}{ Age (ys) } & \multicolumn{2}{|c|}{ Characteristics } & \multirow{2}{*}{ Intervention } & \multirow[t]{2}{*}{ Outcome } \\
\hline & & & $\mathrm{HbA}_{1 \mathrm{c}}(\%)$ & $\begin{array}{l}\text { Insulin doses/ } \\
\text { day }\end{array}$ & & \\
\hline $\begin{array}{l}\text { Bussau et al. } \\
2006 \text { [113] }\end{array}$ & 7 T1D (7) & $21 \pm 3.5$ & $7.4 \pm 0.8$ & NA & $\begin{array}{l}40 \% \mathrm{VO}_{2 \text { peak }} \text { for } 20 \text { min on a cycle ergometer then } \\
\text { immediately engaged in a maximal } 10 \text {-s cycling } \\
\text { sprint (sprint trial) or rested (control trial). [IA -, } \\
\text { DA-]. [PP]. Exercise } \sim 109 \pm 10 \text { min after insulin } \\
\text { injection. }\end{array}$ & $\begin{array}{l}\text { Moderate intensity resulted in a } \\
\text { significant fall in glycaemia in both } \\
\text { trials ( } 3.6 \mathrm{mmol} / \mathrm{L} \text { for sprint training, } 3.1 \\
\text { mmol/L for moderate training). }\end{array}$ \\
\hline $\begin{array}{l}\text { Guelfi et al. } \\
2005 \text { [110] }\end{array}$ & 7 T1D (4) & $21.6 \pm 4$ & $7.4 \pm 1.5$ & $\begin{array}{l}14.8 \pm 7.5 \\
\text { IU.day }^{-1}\end{array}$ & $\begin{array}{l}30 \text { min continuous cycling exercise at } 40 \% \mathrm{VO}_{2 \text { peak }} \text {, } \\
\text { interspersed with } 16 x 4 \text {-s maximal sprint efforts } \\
\text { [IA -, DA-] compared to } 30 \text { min continuous cycling } \\
\text { at } 40 \% \mathrm{VO}_{2 \text { peak }} \text {. [PP]. Exercise } \sim 3.5 \mathrm{~h} \text { after insulin } \\
\text { injection. }\end{array}$ & $\begin{array}{ll}\text { - } & \text { Glucose production }=\uparrow \text { in MOD+HIE vs } \\
\text { MOD } & \text { Glucose utilization }=\downarrow \text { MOD vs MOD }+\mathrm{HIE}\end{array}$ \\
\hline $\begin{array}{l}\text { Guelfi et al. } \\
2007 \text { [103] }\end{array}$ & 9 T1D (5) & $\begin{array}{l}22.6 \pm \\
5.7\end{array}$ & $7.7 \pm 0.8$ & NA & $\begin{array}{l}30 \text { min continuous cycling exercise at } 40 \% \mathrm{VO}_{2 \text { peak }} \\
\text { interspersed with } 16 \times 4-\mathrm{s} \text { maximal sprint efforts. } \\
\text { [IA/DA: euglycaemic clamp]. [PP]. }\end{array}$ & $\begin{array}{l}\text { High-intensity bouts associated with } \\
\text { MOD stimulate a more rapid and greater } \\
\text { increment in endogenous glucose } \\
\text { production during exercise than MOD } \\
\text { alone }\end{array}$ \\
\hline $\begin{array}{l}\text { Iscoe et al. } \\
2006[112]\end{array}$ & $5 \mathrm{~T} 1 \mathrm{D}(4)$ & $\begin{array}{l}35.2 \pm \\
3.0\end{array}$ & $7.0 \pm 0.2$ & $\begin{array}{l}38.8 \pm 5.1 \\
\text { IU.day }^{-1}\end{array}$ & $\begin{array}{l}60 \text { min exercise spinning class (high intensity). } \\
\text { [IA-, DA-]. [PP]. }\end{array}$ & - $\quad$ Blood glucose levels $\downarrow$ significant \\
\hline $\begin{array}{l}\text { Iscoe \& Riddell } \\
2011 \text { [115] }\end{array}$ & $11 \mathrm{~T} 1 \mathrm{D}(5)$ & $\begin{array}{l}35.1 \pm \\
11.6 \\
(18-51)\end{array}$ & $7.8 \pm 0.4$ & $34 \pm 5$ IU.day $^{-1}$ & $\begin{array}{l}\text { - } 45 \text { min of continuous moderate-intensity } \\
\text { cycling exercise at } 55 \% \text { of their } \mathrm{VO}_{2 \text { peak }}(\mathrm{MOD}) \text { or } \\
\text { continuous exercise at } 50 \% \text { of their } \mathrm{VO}_{2 \text { peak }} \text { with } \\
\text { the addition of } 9 \times 15 \mathrm{~s} \text { bouts of } 100 \% \mathrm{VO}_{2 \text { peak }} \\
\text { spaced } 5 \text { min apart (MOD }+\mathrm{HIE}) .[\mathrm{IA}+, \mathrm{DA}+] \\
\text { [PAS]. Exercise } \sim 2 \mathrm{~h} \text { after insulin injection. }\end{array}$ & $\begin{array}{l}\text { - } \quad \text { MOD and MOD+HIE causes similar } \\
\text { reductions in glucose levels during } \\
\text { activity } \\
\text { Addition of HIE is associated with } \\
\text { less risk for late onset post-exercise } \\
\text { hypoglycaemia. }\end{array}$ \\
\hline $\begin{array}{l}\text { Harmer et al. } \\
2008 \text { [114] }\end{array}$ & 7 T1D (5) & $25 \pm 4$ & $\begin{array}{l}8.6 \pm 2.3 \\
\rightarrow 8.1 \pm \\
1.6\end{array}$ & $\begin{array}{l}52.4 \pm 3.8 \\
\text { IU.day }{ }^{-1} 51.2 \pm \\
4.6 \text { IU.day }^{-1}\end{array}$ & $\begin{array}{l}7 \text { weeks of sprint training, 3/wk: } 4-10,30 \text { s all out } \\
\text { sprints, 3-4 min rest). [IA-, DA NA]. [PAS, PP, FS } \\
=\text { NA]. }\end{array}$ & 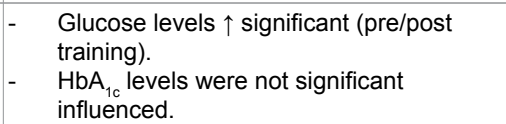 \\
\hline
\end{tabular}

*Data presented as mean \pm SD; No. of Subjects (males) = total number of subjects and the number between brackets are the number of males; MOD: Moderate Intensity Training; IHE/HIE: Intermittent High Intensity Exercise; NA: Not Applicable; IA: Insulin Advice before/after Exercise; DA: Dietary Advice before/during or after Exercise; T1D: Type 1 Diabetes; [VP]: Venous Plasma Glucose; [V]: Venous Whole blood; [P]: Plasma; [C]: Capillary; [IS]: Interstitial Glucose Levels; [M]: Free Muscle Glucose; $\downarrow$ : Decrease; [PAS]: Post Absorptive State (5-11h after last meal); [PP]: Post Prandial (during 4h after meal); [FS]: Fasting State (> 12h after meal); HbA Haemoglobin; $\mathrm{VO}_{2 \text { peak }}$ : Peak Oxygen Uptake

Table 5: Effects of HIE exercise and training on glycaemic control in T1D patients.(Table based on [100])

impairment have become more and more important. PA, such as aerobic exercise, has emerged as a promising low-cost treatment to slow down or even stop the cognitive decline because it supports brain plasticity, neurogenesis and angiogensisin different populations, both healthy and diseased $[24,169,174]$. To date no studies reported the effects of exercise on a DACD in subjects with T1D. However, as glycaemic control plays a central role in a DACD, we could hypothesise that, since exercise is linked to synaptic plasticity, neurogenesis and inflammatory and anti-inflammatory processes (in non-diabetic subjects so far),and improves glycaemic control in subjects with T1D,itcould prevent or 'slow down' a DACD in T1D. Figure 3 gives an overview of the possible pathways and interactions of exercise in a DACD.

Hyperglycaemia is associated with neuroinflammation. Vigorous exercise leads to increased levels of pro-inflammatory cytokines (IL1, IL-10, IL-6 and tumor necrosis factor- $\alpha$ (TNF- $\alpha)$ ) [172,173], but simultaneously cytokine inhibitors and anti-inflammatory cytokines restrict the magnitude and duration of the inflammatory response to exercise [149]. Vigorous exercise will lead to increased levels of VEGF and Il-6, which are associated with angiogenesis [149] and thus can influence cognitive function.

PA seems to be a key intervention to trigger the glycaemic control improvement [100]. BDNF triggers the processes through which neurotrophins mediate energy metabolism and in turn neural plasticity $[169,178,179]$. BDNF levels are inversely associated with fasting plasma glucose and the output of BDNF is inhibited when blood glucose levels are elevated [158]. This suggests that BDNF not only reduces acute blood glucose concentrations but also ameliorates chronic glycaemic control [180], an important cause of a DACD. Until now, no study has looked into the relation between BDNF, exercise and T1D. A vast body of evidence suggests a strong link between circulating BDNF concentrations and cognitive decline [181,182]. Clearly, assumptions can be made that PA can influence the cognitive function in patients with T1D directly through neurogenesis, synaptogenesis and inflammatory responses of exercise, but also through the energy metabolism. Therefore, studies are needed to look at the relationship between PA and cognitive function in T1D.

Another possible mechanism is through energy metabolism. PA and BDNF both trigger the glucose metabolism [158,183]. Previous animal studies focused on the effects of BDNF in diabetic (obese) animals and showed that a peripheral injection of BDNF exhibits hypoglycaemic effects by inducing a hypophagia and reducing plasma insulin levels [184-186]. This indicates that BDNF ameliorates insulin resistance $[184,187,188]$, and therefore has anti-obesity and antidiabetic effects [186]. Tonra et al. [180] showed that BDNF significantly reduced blood glucose and $\mathrm{HbA}_{1 \mathrm{c}}$ when it was administered once or twice a week to diabetic mice for three weeks as compared with controls. This suggests that BDNF not only reduces acute blood glucose concentrations but also ameliorates chronic glycaemic control [180], an important cause of a DACD. A relationship between BDNF and glucose metabolism is also shown in humans. T2D patients have lower levels of plasma BDNF (independently of obesity) compared to nondiabetic subjects $[158,159]$. Krabbe and colleagues [158] showed that T2D is associated with lowered levels of plasma BDNF which are in their turn inversely associated with fasting plasma glucose and that the production of BDNF is inhibited when blood glucose levels are elevated [158]. In contrast, another study reported increased levels of serum BDNF in newly diagnosed patients with T2D [189]. We have to 


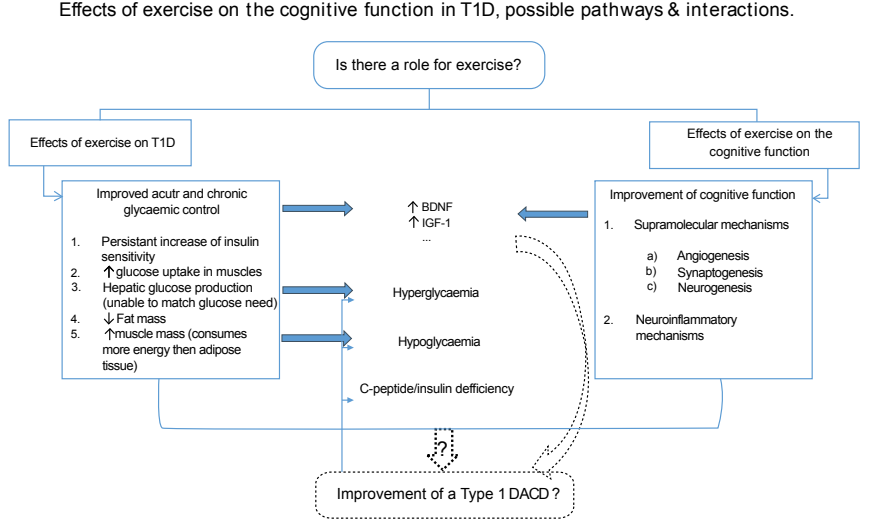

Figure 3: Hypothetical effects of exercise on the cognitive function in T1D. (BDNF = Brain- derived Neurotrophic Factor, IGF-1: Insulin like Growth Factor).

mention that most of the circulating BDNF is stored in the platelets [190], consequently BDNF concentrations are higher in serum [191] than they are in plasma.

\section{Conclusions}

An increasing number of studies (in children and adults) have been published on the central nervous system changes associated with T1D in which it was demonstrated that T1D has an effect on cognitive function. A DACD can be caused by episodes of severe hypoglycaemia (biochemical and neurochemical features), chronic hyperglycaemia (via the polyopol pathway and increased oxidative stress) and c-peptide deficiency.Exercise has been accepted and generally recommended for the management of T1D and have been shown to improve acute and chronic glycaemic control. The addition of brief bouts of high-intensity, sprint-type exercise to aerobic exercise can acutely minimize the risk of sustaining a hypoglycaemic episode. On the level of chronic glycaemic control; regular aerobic training is a favorable tool for the improvement ofthe glycaeted haemoglobin level of a patient with T1D.Since exercise is linked to synaptic plasticity, neurogenesis and inflammatory and anti-inflammatory processes, it could be a tool to prevent or 'slow down' a DACD in T1D. However, no studies have been performed to evaluate the effects of exercise on a DACD. Therefore, future research (cross-sectional, longitudinal and interventional studies) is needed for the evaluation of the effects of exercise and training on the cognitive function in T1D patients.

\section{References}

1. American Diabetes Association (2006) Diagnosis and classification of Diabetes Mellitus - Position Statement. Diabetes Care 29: S43-S48.

2. (1996) Effects of intensive diabetes therapy on neuropsychological function in adults in the Diabetes Control and Complications Trial. Ann Intern Med 124: 379-388.

3. Perantie DC, Wu J, Koller JM, Lim A, Warren SL, et al. (2007) Regional brain volume differences associated with hyperglycemia and severe hypoglycemia in youth with type 1 diabetes. Diabetes Care 30: 2331-2337.

4. Brands AM, Biessels GJ, de Haan EH, Kappelle LJ, Kessels RP (2005) The effects of type 1 diabetes on cognitive performance: a meta-analysis. Diabetes Care 28: 726-735.

5. Li ZG, Zhang W, Sima AA (2005) The role of impaired insulin/IGF action in primary diabetic encephalopathy. Brain Res 1037: 12-24.

6. Mijnhout GS, Scheltens P, Diamant M, Biessels GJ, Wessels AM, et al. (2006) Diabetic encephalopathy: A concept in need of a definition. Diabetologia 49 : 1447-1448.
7. Auer RN (2004) Hypoglycemic brain damage. Metab Brain Dis 19: 169-175.

8. Ryan C, Gurtunca N, Becker D (2005) Hypoglycemia: a complication of diabetes therapy in children. Pediatr Clin North Am 52: 1705-1733.

9. Malone JI, Hanna S, Saporta S, Mervis RF, Park CR, et al. (2008) Hyperglycemia not hypoglycemia alters neuronal dendrites and impairs spatia memory. Pediatr Diabetes 9: 531-539.

10. Wrighten SA, Piroli GG, Grillo CA, Reagan LP (2009) A look inside the diabetic brain: Contributors to diabetes-induced brain aging. Biochim Biophys Acta 1792: $444-453$

11. Grunberger G, Qiang X, Li Z, Mathews ST, Sbrissa D, et al. (2001) Molecular basis for the insulinomimetic effects of C-peptide. Diabetologia 44: 1247-1257.

12. Li ZG, Sima AA (2004) C-peptide and central nervous system complications in diabetes. Exp Diabesity Res 5: 79-90.

13. Li ZG, Zhang W, Sima AA (2002) C-peptide prevents hippocampal apoptosis in type 1 diabetes. Int J Exp Diabetes Res 3: 241-245.

14. Li ZG, Zhang W, Sima AA (2003) C-peptide enhances insulin-mediated cel growth and protection against high glucose-induced apoptosis in SH-SY5Y cells. Diabetes Metab Res Rev 19: 375-385

15. Sima AA, Kamiya H, Li ZG (2004) Insulin, C-peptide, hyperglycemia, and central nervous system complications in diabetes. Eur J Pharmacol 490: 187197

16. Sima AA, Li ZG (2005) The effect of C-peptide on cognitive dysfunction and hippocampal apoptosis in type 1 diabetic rats. Diabetes 54: 1497-1505.

17. Sima AA, Zhang W, Kreipke CW, Rafols JA, Hoffman WH (2009) Inflammation in Diabetic Encephalopathy is Prevented by C-Peptide. Rev Diabet Stud 6 : $37-42$.

18. Sima AA, Zhang W, Muzik O, Kreipke CW, Rafols JA, et al. (2009) Sequential abnormalities in type 1 diabetic encephalopathy and the effects of C-Peptide. Rev Diabet Stud 6: 211-222.

19. Sima AA, Zhang W, Sugimoto K, Henry D, Li Z, et al. (2001) C-peptide prevents and improves chronic Type I diabetic polyneuropathy in the BB/Wor rat Diabetologia 44: 889-897.

20. Sigal RJ, Kenny GP, Wasserman DH, Castaneda-Sceppa C, White RD (2006) Physical activity/exercise and type 2 diabetes: a consensus statement from the American Diabetes Association. Diabetes Care 29: 1433-1438.

21. Frøsig C, Richter EA (2009) Improved insulin sensitivity after exercise: focus on insulin signaling. Obesity (Silver Spring) 17 Suppl 3: S15-20.

22. Colcombe SJ, Kramer AF, Erickson KI, Scalf P, McAuley E, et al. (2004) Cardiovascular fitness, cortical plasticity, and aging. Proc Natl Acad Sci U S A 101: 3316-3321.

23. Masley S, Roetzheim R, Gualtieri T (2009) Aerobic exercise enhances cognitive flexibility. J Clin Psychol Med Settings 16: 186-193.

24. Colcombe S, Kramer AF (2003) Fitness effects on the cognitive function of older adults: a meta-analytic study. Psychol Sci 14: 125-130.

25. Yamanouchi K, Abe R, Takeda A, Atsumi Y, Shichiri M, et al. (2002) The effect of walking before and after breakfast on blood glucose levels in patients with type 1 diabetes treated with intensive insulin therapy. Diabetes Res Clin Pract 58: 11-18.

26. Perantie DC, Lim A, Wu J, Weaver P, Warren SL, et al. (2008) Effects of prior hypoglycemia and hyperglycemia on cognition in children with type 1 diabetes mellitus. Pediatr Diabetes 9: 87-95

27. Ohmann S, Popow C, Rami B, König M, Blaas S, et al. (2010) Cognitive functions and glycemic control in children and adolescents with type 1 diabetes. Psychol Med 40: 95-103.

28. Hannonen R, Komulainen J, Riikonen R, Ahonen T, Eklund K, et al. (2012) Academic skills in children with early-onset type 1 diabetes: the effects of diabetes-related risk factors. Dev Med Child Neurol 54: 457-463.

29. Hannonen R, Tupola S, Ahonen T, Riikonen R (2003) Neurocognitive functioning in children with type-1 diabetes with and without episodes of severe hypoglycaemia. Dev Med Child Neurol 45: 262-268.

30. Hershey T, Perantie DC, Warren SL, Zimmerman EC, Sadler M, et al. (2005) Frequency and timing of severe hypoglycemia affects spatial memory in children with type 1 diabetes. Diabetes Care 28: 2372-2377. 
31. Hershey T, Lillie R, Sadler M, White NH (2004) A prospective study of severe hypoglycemia and long-term spatial memory in children with type 1 diabetes. Pediatr Diabetes 5: 63-71.

32. Hershey T, Lillie R, Sadler M, White NH (2003) Severe hypoglycemia and longterm spatial memory in children with type 1 diabetes mellitus: a retrospective study. J Int Neuropsychol Soc 9: 740-750.

33. Hershey T, Bhargava N, Sadler M, White NH, Craft S (1999) Conventional versus intensive diabetes therapy in children with type 1 diabetes: effects on memory and motor speed. Diabetes Care 22: 1318-1324.

34. Crawford SG, Kaplan BJ, Field LL (1995) Absence of an association between insulin-dependent diabetes mellitus and developmental learning difficulties. Hereditas 122: 73-78.

35. Rovet JF, Ehrlich RM, Hoppe M (1988) Specific intellectual deficits in children with early onset diabetes mellitus. Child Dev 59: 226-234.

36. Northam EA, Lin A (2010) Hypoglycaemia in childhood onset type 1 diabetespart villain, but not the only one. Pediatr Diabetes 11: 134-141.

37. Ryan C, Vega A, Drash A (1985) Cognitive deficits in adolescents who developed diabetes early in life. Pediatrics 75: 921-927.

38. Shehata G, Eltayeb A (2010) Cognitive function and event-related potentials in children with type 1 diabetes mellitus. J Child Neurol 25: 469-474.

39. Kaufman FR, Epport K, Engilman R, Halvorson M (1999) Neurocognitive functioning in children diagnosed with diabetes before age 10 years. J Diabetes Complications 13: 31-38.

40. Patiño-Fernández AM, Delamater AM, Applegate EB, Brady E, Eidson M, e al. (2010) Neurocognitive functioning in preschool-age children with type 1 diabetes mellitus. Pediatr Diabetes 11: 424-430.

41. Aye T, Reiss AL, Kesler S, Hoang S, Drobny J, et al. (2011) The feasibility of detecting neuropsychologic and neuroanatomic effects of type 1 diabetes in young children. Diabetes Care 34: 1458-1462.

42. Holmes CS, Dunlap WP, Chen RS, Cornwell JM (1992) Gender differences in the learning status of diabetic children. J Consult Clin Psychol 60: 698-704.

43. Ryan CM, Williams TM (1993) Effects of insulin-dependent diabetes on learning and memory efficiency in adults. J Clin Exp Neuropsychol 15: 685-700.

44. Ryan CM, Williams TM, Finegold DN, Orchard TJ (1993) Cognitive dysfunction in adults with type 1 (insulin-dependent) diabetes mellitus of long duration: effects of recurrent hypoglycaemia and other chronic complications. Diabetologia 36: 329-334.

45. Ryan CM, Williams TM, Orchard TJ, Finegold DN (1992) Psychomotor slowing is associated with distal symmetrical polyneuropathy in adults with diabetes mellitus. Diabetes 41: 107-113.

46. Wessels AM, Rombouts SA, Remijnse PL, Boom Y, Scheltens $P$, et al. (2007) Cognitive performance in type 1 diabetes patients is associated with cerebral white matter volume. Diabetologia 50: 1763-1769.

47. Brands AM, Kessels RP, Hoogma RP, Henselmans JM, van der Beek Boter JW, et al. (2006) Cognitive performance, psychological well-being, and brain magnetic resonance imaging in older patients with type 1 diabetes. Diabetes 55. $1800-1806$

48. Deary IJ, Crawford JR, Hepburn DA, Langan SJ, Blackmore LM, et al. (1993) Severe hypoglycemia and intelligence in adult patients with insulin-treated diabetes. Diabetes 42: 341-344.

49. Franceschi M, Cecchetto R, Minicucci F, Smizne S, Baio G, et al. (1984) Cognitive processes in insulin-dependent diabetes. Diabetes Care 7: 228-231.

50. Clausen TD, Mortensen EL, Schmidt L, Mathiesen ER, Hansen T, et al. (2011) Cognitive function in adult offspring of women with Type 1 diabetes. Diabe Med 28: 838-844.

51. Ly TT, Anderson M, McNamara KA, Davis EA, Jones TW (2011) Neurocognitive outcomes in young adults with early-onset type 1 diabetes: a prospective follow-up study. Diabetes Care 34: 2192-2197.

52. Lawson JS, Erdahl DL, Monga TN, Bird CE, Donald MW, et al. (1984) Neuropsychological function in diabetic patients with neuropathy. $\mathrm{Br} J$ Psychiatry 145: 263-268.

53. Kramer L, Fasching P, Madl C, Schneider B, Damjancic P, et al. (1998) Previous episodes of hypoglycemic coma are not associated with permanent cognitive brain dysfunction in IDDM patients on intensive insulin treatment. Diabetes 47: 1909-1914.
54. Sachon C, Grimaldi A, Digy JP, Pillon B, Dubois B, et al. (1992) Cognitive function, insulin-dependent diabetes and hypoglycaemia. J Intern Med 231 471-475.

55. Geddes J, Deary IJ, Frier BM (2008) Effects of acute insulin-induced hypoglycaemia on psychomotor function: people with type 1 diabetes are less affected than non-diabetic adults. Diabetologia 51: 1814-1821.

56. Maran A, Lomas J, Macdonald IA, Amiel SA (1995) Lack of preservation of higher brain function during hypoglycaemia in patients with intensively-treated IDDM. Diabetologia 38: 1412-1418.

57. Blackman JD, Towle VL, Sturis J, Lewis GF, Spire JP, et al. (1992) Hypoglycemic thresholds for cognitive dysfunction in IDDM. Diabetes 41: 392-399.

58. Wright RJ, Frier BM, Deary IJ (2009) Effects of acute insulin-induced hypoglycemia on spatial abilities in adults with type 1 diabetes. Diabetes Care 32: $1503-1506$.

59. Northam EA, Anderson PJ, Jacobs R, Hughes M, Warne GL, et al. (2001) Neuropsychological profiles of children with type 1 diabetes 6 years after disease onset. Diabetes Care 24: 1541-1546.

60. Ryan CM (2006) Why is cognitive dysfunction associated with the development of diabetes early in life? The diathesis hypothesis. Pediatr Diabetes 7: 289-297.

61. Diabetes Control and Complications Trial/Epidemiology of Diabetes Interventions and Complications Study Research Group, Jacobson AM, Musen G, Ryan CM, Silvers N, et al. (2007) Long-term effect of diabetes and its treatment on cognitive function. N Engl J Med 356: 1842-1852.

62. Howorka K, Pumprla J, Saletu B, Anderer P, Krieger M, et al. (2000) Decrease of vigilance assessed by EEG-mapping in type I diabetic patients with history of recurrent severe hypoglycaemia. Psychoneuroendocrinology 25: 85-105.

63. Reichard P, Pihl M, Rosenqvist U, Sule J (1996) Complications in IDDM are caused by elevated blood glucose level: the Stockholm Diabetes Intervention Study (SDIS) at 10-year follow up. Diabetologia 39: 1483-1488.

64. Knight S, Northam E, Donath S, Gardner A, Harkin N, et al. (2009) Improvements in cognition, mood and behaviour following commencement of continuous subcutaneous insulin infusion therapy in children with type 1 diabetes mellitus: a pilot study. Diabetologia 52: 193-198.

65. Jacobson AM, Ryan CM, Cleary PA, Waberski BH, Weinger K, et al. (2011) Biomedical risk factors for decreased cognitive functioning in type 1 diabetes: an 18 year follow-up of the Diabetes Control and Complications Trial (DCCT) cohort. Diabetologia 54: 245-255.

66. Ferguson SC, Blane A, Perros P, McCrimmon RJ, Best JJ, et al. (2003) Cognitive ability and brain structure in type 1 diabetes: relation to microangiopathy and preceding severe hypoglycemia. Diabetes 52: 149-156.

67. Warren RE, Allen KV, Sommerfield AJ, Deary IJ, Frier BM (2004) Acute hypoglycemia impairs nonverbal intelligence: importance of avoiding ceiling effects in cognitive function testing. Diabetes Care 27: 1447-1448.

68. Pramming S, Thorsteinsson B, Stigsby B, Binder C (1988) Glycaemic threshold for changes in electroencephalograms during hypoglycaemia in patients with insulin dependent diabetes. Br Med J (Clin Res Ed) 296: 665-667.

69. Wysocki T, Harris MA, Mauras N, Fox L, Taylor A, et al. (2003) Absence of adverse effects of severe hypoglycemia on cognitive function in school-aged children with diabetes over 18 months. Diabetes Care 26: 1100-1105.

70. Gschwend S, Ryan C, Atchison J, Arslanian S, Becker D (1995) Effects of acute hyperglycemia on mental efficiency and counterregulatory hormones in adolescents with insulin-dependent diabetes mellitus. J Pediatr 126: 178-184.

71. Kelly D, Hamilton JK, Riddell MC (2010) Blood glucose levels and performance in a sports cAMP for adolescents with type 1 diabetes mellitus: a field study. Int J Pediatr 2010

72. Draelos MT, Jacobson AM, Weinger K, Widom B, Ryan CM, et al. (1995) Cognitive function in patients with insulin-dependent diabetes mellitus during hyperglycemia and hypoglycemia. Am J Med 98: 135-144.

73. Fanelli CG, Pampanelli S, Porcellati F, Bartocci L, Scionti L, et al. (2003) Rate of fall of blood glucose and physiological responses of counterregulatory hormones, clinical symptoms and cognitive function to hypoglycaemia in Type diabetes mellitus in the postprandial state. Diabetologia 46: 53-64.

74. Wredling R, Levander S, Adamson U, Lins PE (1990) Permanent neuropsychological impairment after recurrent episodes of severe hypoglycaemia in man. Diabetologia 33: 152-157. 
75. McAulay V, Deary IJ, Sommerfield AJ, Frier BM (2006) Attentional functioning is impaired during acute hypoglycaemia in people with Type 1 diabetes. Diabet Med 23: 26-31.

76. Sommerfield AJ, Deary IJ, McAulay V, Frier BM (2003) Short-term, delayed, and working memory are impaired during hypoglycemia in individuals with type 1 diabetes. Diabetes Care 26: 390-396.

77. Ewing FM, Deary IJ, McCrimmon RJ, Strachan MW, Frier BM (1998) Effect of acute hypoglycemia on visual information processing in adults with type 1 diabetes mellitus. Physiol Behav 64: 653-660.

78. Strachan MW, Frier BM, Deary IJ (2003) Type 2 diabetes and cognitive impairment. Diabet Med 20: 1-2

79. Gold AE, Deary IJ, MacLeod KM, Thomson KJ, Frier BM (1995) Cognitive function during insulin-induced hypoglycemia in humans: short-term cerebral adaptation does not occur. Psychopharmacology (Berl) 119: 325-333.

80. McCrimmon RJ, Frier BM (1997) Symptomatic and physiological responses to hypoglycaemia induced by human soluble insulin and the analogue Lispro human insulin. Diabet Med 14: 929-936.

81. Puente EC, Silverstein J, Bree AJ, Musikantow DR, Wozniak DF, et al. (2010) Recurrent moderate hypoglycemia ameliorates brain damage and cognitive dysfunction induced by severe hypoglycemia. Diabetes 59: 1055-1062.

82. Chabriat H, Sachon C, Levasseur M, Grimaldi A, Pappata S, et al. (1994) Brain metabolism after recurrent insulin induced hypoglycaemic episodes: a PET study. J Neurol Neurosurg Psychiatry 57: 1360-1365.

83. Brands AM, Kessels RP, de Haan EH, Kappelle LJ, Biessels GJ (2004) Cerebral dysfunction in type 1 diabetes: effects of insulin, vascular risk factors and blood-glucose levels. Eur J Pharmacol 490: 159-168

84. Keymeulen B, Jacobs A, de Metz K, de Sadeleer C, Bossuyt A, et al. (1995) Regional cerebral hypoperfusion in long-term type 1 (insulin-dependent) diabetic patients: relation to hypoglycaemic events. Nucl Med Commun 16 10-16.

85. Wessels AM, Rombouts SA, Simsek S, Kuijer JP, Kostense PJ, et al. (2006) Microvascular disease in type 1 diabetes alters brain activation: a functional magnetic resonance imaging study. Diabetes 55: 334-340.

86. Johnson PC, Brendel K, Meezan E (1982) Thickened cerebral cortical capillary basement membranes in diabetics. Arch Pathol Lab Med 106: 214-217.

87. Tallroth G, Ryding E, Agardh CD (1993) The influence of hypoglycaemia on regional cerebral blood flow and cerebral volume in type 1 (insulin-dependent) diabetes mellitus. Diabetologia 36: 530-535.

88. MacLeod KM, Hepburn DA, Deary IJ, Goodwin GM, Dougall N, et al. (1994) Regional cerebral blood flow in IDDM patients: effects of diabetes and of recurrent severe hypoglycaemia. Diabetologia 37: 257-263.

89. MacLeod KM, Gold AE, Ebmeier KP, Hepburn DA, Deary IJ, et al. (1996) The effects of acute hypoglycemia on relative cerebral blood flow distribution in patients with type I (insulin-dependent) diabetes and impaired hypoglycemia awareness. Metabolism 45: 974-980.

90. [No authors listed] (1993) The effect of intensive treatment of diabetes on the development and progression of long-term complications in insulin-dependent diabetes mellitus. The Diabetes Control and Complications Trial Research Group. N Engl J Med 329: 977-986.

91. Bolo NR, Musen G, Jacobson AM, Weinger K, McCartney RL, et al. (2011) Brain activation during working memory is altered in patients with type 1 diabetes during hypoglycemia. Diabetes 60: 3256-3264.

92. Hoffman WH, Artlett CM, Zhang W, Kreipke CW, Passmore GG, et al. (2008) Receptor for advanced glycation end products and neuronal deficit in the fata brain edema of diabetic ketoacidosis. Brain Res 1238: 154-162.

93. Goh SY, Cooper ME (2008) Clinical review: The role of advanced glycation end products in progression and complications of diabetes. J Clin Endocrino Metab 93: 1143-1152.

94. Love S (1999) Oxidative stress in brain ischemia. Brain Pathol 9: 119-131.

95. Kaminski KA, Bonda TA, Korecki J, Musial WJ (2002) Oxidative stress and neutrophil activation--the two keystones of ischemia/reperfusion injury. Int $J$ Cardiol 86: 41-59.

96. Voll CL, Auer RN (1991) Insulin attenuates ischemic brain damage independent of its hypoglycemic effect. J Cereb Blood Flow Metab 11: 1006-1014.
97. Heyman E, Delamarche P, Berthon P, Meeusen R, Briard D, et al. (2007) Alteration in sympathoadrenergic activity at rest and during intense exercise despite normal aerobic fitness in late pubertal adolescent girls with type 1 diabetes. Diabetes Metab 33: 422-429.

98. Raile K, Kapellen T, Schweiger A, Hunkert F, Nietzschmann U, et al. (1999) Physical activity and competitive sports in children and adolescents with type 1 diabetes. Diabetes Care 22: 1904-1905.

99. MacDonald MJ (1987) Postexercise late-onset hypoglycemia in insulindependent diabetic patients. Diabetes Care 10: 584-588.

100. Tonoli C, Heyman E, Roelands B, Buyse L, Cheung SS, et al. (2012) Effects of different types of acute and chronic (training) exercise on glycaemic control in type 1 diabetes mellitus: a meta-analysis. Sports Med 42: 1059-1080.

101. Rabasa-Lhoret R, Bourque J, Ducros F, Chiasson JL (2001) Guidelines for premeal insulin dose reduction for postprandial exercise of different intensities and durations in type 1 diabetic subjects treated intensively with a basal-bolus insulin regimen (ultralente-lispro). Diabetes Care 24: 625-630.

102. Riddell M, Perkins BA (2009) Exercise and glucose metabolism in persons with diabetes mellitus: perspectives on the role for continuous glucose monitoring J Diabetes Sci Technol 3: 914-923.

103. Guelfi KJ, Ratnam N, Smythe GA, Jones TW, Fournier PA (2007) Effect of intermittent high-intensity compared with continuous moderate exercise on glucose production and utilization in individuals with type 1 diabetes. Am J Physiol Endocrinol Metab 292: E865-870.

104. Jimenez C, Santiago M, Sitler M, Boden G, Homko C (2009) Insulin-sensitivity response to a single bout of resistive exercise in type 1 diabetes mellitus. $J$ Sport Rehabil 18: 564-571.

105. lafusco D (2006) Diet and physical activity in patients with type 1 diabetes Acta Biomed 77 Suppl 1: 41-46.

106. Zander E, Bruns W, Wulfert P, Besch W, Lubs D, et al (1983) Muscular exercise in type I-diabetics. I. Different metabolic reactions during heavy muscular work in dependence on actual insulin availability. Exp Clin Endocrinol 82: 78-90.

107. Heyman E, Briard D, Gratas-Delamarche A, Delamarche P, De Kerdanet M (2005) Normal physical working capacity in prepubertal children with type 1 diabetes compared with healthy controls. Acta Paediatr 94: 1389-1394.

108. Tansey MJ, Tsalikian E, Beck RW, Mauras N, Buckingham BA, et al. (2006) The effects of aerobic exercise on glucose and counterregulatory hormone concentrations in children with type 1 diabetes. Diabetes Care 29: 20-25.

109. Poortmans JR, Saerens P, Edelman R, Vertongen F, Dorchy H (1986) Influence of the degree of metabolic control on physical fitness in type diabetic adolescents. Int J Sports Med 7: 232-235

110. Guelfi KJ, Jones TW, Fournier PA (2005) The decline in blood glucose levels is less with intermittent high-intensity compared with moderate exercise in individuals with type 1 diabetes. Diabetes Care 28: 1289-1294

111. West DJ, Stephens JW, Bain SC, Kilduff LP, Luzio S, et al. (2011) A combined insulin reduction and carbohydrate feeding strategy $30 \mathrm{~min}$ before running best preserves blood glucose concentration after exercise through improved fuel oxidation in type 1 diabetes mellitus. J Sports Sci 29: 279-289.

112. Iscoe KE, Campbell JE, Jamnik V, Perkins BA, Riddell MC (2006) Efficacy of continuous real-time blood glucose monitoring during and after prolonged high-intensity cycling exercise: spinning with a continuous glucose monitoring system. Diabetes Technol Ther 8: 627-635

113. Bussau VA, Ferreira LD, Jones TW, Fournier PA (2006) The 10-s maxima sprint: a novel approach to counter an exercise-mediated fall in glycemia in individuals with type 1 diabetes. Diabetes Care 29: 601-606.

114. Harmer AR, Chisholm DJ, McKenna MJ, Hunter SK, Ruell PA, et al. (2008) Sprint training increases muscle oxidative metabolism during high-intensity exercise in patients with type 1 diabetes. Diabetes Care 31: 2097-2102.

115. Iscoe KE, Riddell MC (2011) Continuous moderate-intensity exercise with or without intermittent high-intensity work: effects on acute and late glycaemia in athletes with Type 1 diabetes mellitus. Diabet Med 28: 824-832.

116. Graveling AJ, Frier BM (2010) Risks of marathon running and hypoglycaemia in Type 1 diabetes. Diabet Med 27: 585-588.

117. Toni S, Reali MF, Barni F, Lenzi L, Festini F (2006) Managing insulin therapy during exercise in type 1 diabetes mellitus. Acta Biomed 77 Suppl 1: 34-40. 
118. Bussau VA, Ferreira LD, Jones TW, Fournier PA (2007) A 10-s sprint performed prior to moderate-intensity exercise prevents early post-exercise fall in glycaemia in individuals with type 1 diabetes. Diabetologia 50: 18151818.

119. Zinman B, Murray FT, Vranic M, Albisser AM, Leibel BS, et al. (1977) Glucoregulation during moderate exercise in insulin treated diabetics. $\mathrm{J}$ Clin Endocrinol Metab 45: 641-652.

120. Laaksonen DE, Atalay M, Niskanen LK, Mustonen J, Sen CK, et al. (2000) Aerobic exercise and the lipid profile in type 1 diabetic men: a randomized controlled trial. Med Sci Sports Exerc 32: 1541-1548.

121.Lehmann R, Kaplan V, Bingisser R, Bloch KE, Spinas GA (1997) Impact of physical activity on cardiovascular risk factors in IDDM. Diabetes Care 20: 1603-1611.

122. Ramalho AC, de Lourdes Lima M, Nunes F, Cambuí Z, Barbosa C, et al. (2006) The effect of resistance versus aerobic training on metabolic control in patients with type-1 diabetes mellitus. Diabetes Res Clin Pract 72: 271-276.

123. Wallberg-Henriksson H, Gunnarsson R, Rössner S, Wahren J (1986) LongTerm Physical Training in Female Type 1 (insulin-dependent) diabetic patients: absence of significant effect on glycaemic control and lipoprotein levels. Diabetologia 29: 53-57.

124.Zinman B, Zuniga-Guajardo S, Kelly D (1984) Comparison of the acute and long-term effects of exercise on glucose control in type I diabetes. Diabetes Care 7: 515-519.

125. Marrero DG, Fremion AS, Golden MP (1988) Improving compliance with exercise in adolescents with insulin-dependent diabetes mellitus: results of a self-motivated home exercise program. Pediatrics 81: 519-525.

126. Michaliszyn SF, Faulkner MS (2010) Physical activity and sedentary behavior in adolescents with type 1 diabetes. Res Nurs Health 33: 441-449.

127. Ruzic L, Sporis G, Matkovic BR (2008) High volume-low intensity exercise camp and glycemic control in diabetic children. J Paediatr Child Health 44 122-128.

128. Sideraviciūte S, Gailiūniene A, Visagurskiene K, Vizbaraite D (2006) The effect of long-term swimming program on glycemia control in 14-19-year aged healthy girls and girls with type 1 diabetes mellitus. Medicina (Kaunas) 42: 513-518.

129.Dahl-Jørgensen K, Meen HD, Hanssen KF, Aagenaes O (1980) The effect of exercise on diabetic control and hemoglobin A1 (HbA1) in children. Acta Paediatr Scand Suppl 283: 53-56.

130. Huttunen NP, Länkelä SL, Knip M, Lautala P, Käär ML, et al. (1989) Effect of once-a-week training program on physical fitness and metabolic control in children with IDDM. Diabetes Care 12: 737-740.

131. Rowland TW, Swadba LA, Biggs DE, Burke EJ, Reiter EO (1985) Glycemic control with physical training in insulin-dependent diabetes mellitus. Am J Dis Child 139: 307-310.

132. Baldi JC, Cassuto NA, Foxx-Lupo WT, Wheatley CM, Snyder EM (2010) Glycemic status affects cardiopulmonary exercise response in athletes with type I diabetes. Med Sci Sports Exerc 42: 1454-1459.

133. Svensson MK, Eriksson JW (2011) Change in the amount of body fat and IL-6 levels is related to altered insulin sensitivity in type 1 diabetes patients with or without diabetic nephropathy. Horm Metab Res 43: 209-215.

134.Perseghin G, Price TB, Petersen KF, Roden M, Cline GW, et al. (1996) Increased glucose transport-phosphorylation and muscle glycogen synthesis after exercise training in insulin-resistant subjects. N Engl J Med 335: 13571362.

135. Durak EP, Jovanovic-Peterson L, Peterson CM (1990) Randomized crossover study of effect of resistance training on glycemic control, muscular strength, and cholesterol in type I diabetic men. Diabetes Care 13: 1039-1043.

136. Ismail I, Keating SE, Baker MK, Johnson NA (2012) A systematic review and meta-analysis of the effect of aerobic vs. resistance exercise training on visceral fat. Obes Rev 13: 68-91.

137. Tresierras MA, Balady GJ (2009) Resistance training in the treatment of diabetes and obesity: mechanisms and outcomes. J Cardiopulm Rehabil Prev 29: $67-75$

138. Irvine C, Taylor NF (2009) Progressive resistance exercise improves glycaemic control in people with type 2 diabetes mellitus: a systematic review. Aust J Physiother 55: 237-246.
139. Sundell J (2011) Resistance Training Is an Effective Tool against Metabolic and Frailty Syndromes. Adv Prev Med 2011: 984683.

140. Heymsfield SB, Gallagher D, Kotler DP, Wang Z, Allison DB, et al. (2002) Body-size dependence of resting energy expenditure can be attributed to nonenergetic homogeneity of fat-free mass. Am J Physiol Endocrinol Metab 282: E132-138.

141.D'hooge R, Hellinckx T, Van Laethem C, Stegen S, De Schepper J, et al. (2011) Influence of combined aerobic and resistance training on metabolic control, cardiovascular fitness and quality of life in adolescents with type 1 diabetes: a randomized controlled trial. Clin Rehabil 25: 349-359.

142. Bernardini AL, Vanelli M, Chiari G, lovane B, Gelmetti C, et al. (2004) Adherence to physical activity in young people with type 1 diabetes. Acta Biomed 75: 153-157.

143. Mosher PE, Nash MS, Perry AC, LaPerriere AR, Goldberg RB (1998) Aerobic circuit exercise training: effect on adolescents with well-controlled insulindependent diabetes mellitus. Arch Phys Med Rehabil 79: 652-657.

144. Heyman E, Toutain C, Delamarche P, Berthon P, Briard D, et al. (2007) Exercise training and cardiovascular risk factors in type 1 diabetic adolescent girls. Pediatr Exerc Sci 19: 408-419.

145. Harmer AR, Chisholm DJ, McKenna MJ, Morris NR, Thom JM, et al. (2007) High-intensity training improves plasma glucose and acid-base regulation during intermittent maximal exercise in type 1 diabetes. Diabetes Care 30 : 1269-1271.

146. Hillman $\mathrm{CH}$, Erickson KI, Kramer AF (2008) Be smart, exercise your heart exercise effects on brain and cognition. Nat Rev Neurosci 9: 58-65.

147.van Praag $\mathrm{H}$ (2008) Neurogenesis and exercise: past and future directions Neuromolecular Med 10: 128-140.

148. Thomas AG, Dennis A, Bandettini PA, Johansen-Berg H (2012) The effects of aerobic activity on brain structure. Front Psychol 3: 86

149. Foster PP, Rosenblatt KP, Kuljiß̊ plasticity, implications for mild cognitive impairment and Alzheimer's disease. Front Neurol 2: 28.

150. Lista I, Sorrentino G (2010) Biological mechanisms of physical activity in preventing cognitive decline. Cell Mol Neurobiol 30: 493-503.

151.van Praag H, Shubert T, Zhao C, Gage FH (2005) Exercise enhances learning and hippocampal neurogenesis in aged mice. J Neurosci 25: 8680-8685.

152. Trejo JL, Carro E, Torres-Aleman I (2001) Circulating insulin-like growth factor I mediates exercise-induced increases in the number of new neurons in the adult hippocampus. J Neurosci 21: 1628-1634.

153. Christie BR, Eadie BD, Kannangara TS, Robillard JM, Shin J, et al. (2008) Exercising our brains: how physical activity impacts synaptic plasticity in the dentate gyrus. Neuromolecular Med 10: 47-58.

154. Gatti R, De Palo EF, Antonelli G, Spinella P (2012) IGF-I/IGFBP system: metabolism outline and physical exercise. J Endocrinol Invest 35: 699-707.

155. Fabel K, Fabel K, Tam B, Kaufer D, Baiker A, et al. (2003) VEGF is necessary for exercise-induced adult hippocampal neurogenesis. Eur J Neurosci 18 2803-2812.

156. Castellano V, White LJ (2008) Serum brain-derived neurotrophic facto response to aerobic exercise in multiple sclerosis. J Neurol Sci 269: 85-91.

157. Aydemir C, Yalcin ES, Aksaray S, Kisa C, Yildirim SG, et al. (2006) Brainderived neurotrophic factor (BDNF) changes in the serum of depressed women. Prog Neuropsychopharmacol Biol Psychiatry 30: 1256-1260.

158. Krabbe KS, Nielsen AR, Krogh-Madsen R, Plomgaard $P$, Rasmussen $P$, et al. (2007) Brain-derived neurotrophic factor (BDNF) and type 2 diabetes. Diabetologia 50: 431-438.

159. Fujinami A, Ohta K, Obayashi H, Fukui M, Hasegawa G,et al. (2008) Serum brain-derived neurotrophic factor in patients with type 2 diabetes mellitus: Relationship to glucose metabolism and biomarkers of insulin resistance. Clin Biochem 41: 812-817.

160. Erickson KI, Prakash RS, Voss MW, Chaddock L, Heo S, et al. (2010) Brain-derived neurotrophic factor is associated with age-related decline in hippocampal volume. J Neurosci 30: 5368-5375. 
Citation: Tonoli C, Heyman E, Roelands B, Buyse L, Piacentini MF, et al. (2013) Diabetes Associated Cognitive Decline, is there a Role for Exercise? J Diabetes Metab S10: 006. doi:10.4172/2155-6156.S10-006

Page 14 of 14

161. Erickson KI, Voss MW, Prakash RS, Basak C, Szabo A, et al. (2011) Exercise training increases size of hippocampus and improves memory. Proc Natl Acad Sci U S A 108: 3017-3022.

162. Schulz KH, Gold SM, Witte J, Bartsch K, Lang UE, et al. (2004) Impact of aerobic training on immune-endocrine parameters, neurotrophic factors, quality of life and coordinative function in multiple sclerosis. J Neurol Sci 225 11-18.

163. Baker LD, Frank LL, Foster-Schubert K, Green PS, Wilkinson CW, et al. (2010) Effects of aerobic exercise on mild cognitive impairment: a controlled trial. Arch Neurol 67: 71-79.

164.Zoladz JA, Pilc A, Majerczak J, Grandys M, Zapart-Bukowska J, et al. (2008) Endurance training increases plasma brain-derived neurotrophic factor concentration in young healthy men. J Physiol Pharmacol 59 Suppl 7: 119132.

165. Goekint M, Roelands B, De Pauw K, Knaepen K, Bos I, et al. (2010) Does a period of detraining cause a decrease in serum brain-derived neurotrophic factor? Neurosci Lett 486: 146-149.

166. Schiffer T, Schulte S, Hollmann W, Bloch W, Strüder HK (2009) Effects of strength and endurance training on brain-derived neurotrophic factor and insulin-like growth factor 1 in humans. Horm Metab Res 41: 250-254.

167. Goekint M, De Pauw K, Roelands B, Njemini R, Bautmans I, et al. (2010) Strength training does not influence serum brain-derived neurotrophic factor. Eur J Appl Physiol 110: 285-293.

168. Ferris LT, Williams JS, Shen CL (2007) The effect of acute exercise on serum brain-derived neurotrophic factor levels and cognitive function. Med Sci Sports Exerc 39: 728-734.

169. Knaepen K, Goekint M, Heyman EM, Meeusen R (2010) Neuroplasticity Exercise-Induced Response of Peripheral Brain-Derived Neurotrophic Factor A Systematic Review of Experimental Studies in Human Subjects. Sports Med 40: 765-801.

170.Li ZG, Zhang W, Grunberger G, Sima AA (2002) Hippocampal neuronal apoptosis in type 1 diabetes. Brain Res 946: 221-231.

171. Nieman DC (2003) Current perspective on exercise immunology. Curr Sports Med Rep 2: 239-242.

172. Northoff H, Weinstock C, Berg A (1994) The cytokine response to strenuous exercise. Int J Sports Med 15 Suppl 3: S167-171.

173.Pedersen BK, Ostrowski K, Rohde T, Bruunsgaard H (1998) The cytokine response to strenuous exercise. Can J Physiol Pharmacol 76: 505-511.

174. Cassilhas RC, Lee KS, Fernandes J, Oliveira MG, Tufik S, et al. (2012) Spatial memory is improved by aerobic and resistance exercise through divergent molecular mechanisms. Neuroscience 202: 309-317.

175. Heyman E, Gamelin FX, Goekint M, Piscitelli F, Roelands B, et al. (2012) Intense exercise increases circulating endocannabinoid and BDNF levels in humans-possible implications for reward and depression. Psychoneuroendocrinology 37: 844-851.

176. Wong CH, Chiang YC, Wai JP, Lo FS, Yeh CH, et al. (2011) Effects of a homebased aerobic exercise programme in children with type 1 diabetes mellitus. J Clin Nurs 20: 681-691.
177. Dishman RK, Berthoud HR, Booth FW, Cotman CW, Edgerton VR, et al (2006) Neurobiology of exercise. Obesity (Silver Spring) 14: 345-356.

178. Vaynman S, Ying Z, Gomez-Pinilla F (2004) Hippocampal BDNF mediates the efficacy of exercise on synaptic plasticity and cognition. Eur $\mathrm{J}$ Neurosci 20: $2580-2590$.

179.van Praag H, Kempermann G, Gage FH (1999) Running increases cel proliferation and neurogenesis in the adult mouse dentate gyrus. Nat Neurosci 2: $266-270$

180. Tonra JR, Ono M, Liu X, Garcia K, Jackson C, et al. (1999) Brain-derived neurotrophic factor improves blood glucose control and alleviates fasting hyperglycemia in C57BLKS-Lepr(db)/lepr(db) mice. Diabetes 48: 588-594.

181. Chen B, Dowlatshahi D, MacQueen GM, Wang JF, Young LT (2001) Increased hippocampal BDNF immunoreactivity in subjects treated with antidepressant medication. Biol Psychiatry 50: 260-265.

182. Del Arco A, Segovia G, de Blas M, Garrido P, Acuña-Castroviejo D, et al (2011) Prefrontal cortex, caloric restriction and stress during aging: studies on dopamine and acetylcholine release, BDNF and working memory. Behav Brain Res 216: 136-145.

183. Yamanaka M, Itakura Y, Tsuchida A, Nakagawa T, Taiji M (2008) Brainderived neurotrophic factor (BDNF) prevents the development of diabetes in prediabetic mice. Biomed Res 29: 147-153.

184. Nakagawa T, Tsuchida A, Itakura Y, Nonomura T, Ono M, et al. (2000) Brainderived neurotrophic factor regulates glucose metabolism by modulating energy balance in diabetic mice. Diabetes 49: 436-444.

185. Ono M, Ichihara J, Nonomura T, Itakura Y, Taiji M, et al. (1997) Brain-derived neurotrophic factor reduces blood glucose level in obese diabetic mice but not in normal mice. Biochem Biophys Res Commun 238: 633-637.

186. Yamanaka M, Itakura $\mathrm{Y}$, Ono-Kishino M, Tsuchida A, Nakagawa T, et al (2008) Intermittent administration of brain-derived neurotrophic factor (BDNF) ameliorates glucose metabolism and prevents pancreatic exhaustion in diabetic mice. J Biosci Bioeng 105: 395-402.

187. Ono M, Itakura Y, Nonomura T, Nakagawa T, Nakayama C, et al. (2000) Intermittent administration of brain-derived neurotrophic factor ameliorates glucose metabolism in obese diabetic mice. Metabolism 49: 129-133.

188. Tonra JR (1999) Classical and novel directions in neurotrophin transport and research: anterograde transport of brain-derived neurotrophic factor by sensory neurons. Microsc Res Tech 45: 225-232.

189. Suwa M, Kishimoto H, Nofuji Y, Nakano H, Sasaki H, et al. (2006) Serum brainderived neurotrophic factor level is increased and associated with obesity in newly diagnosed female patients with type 2 diabetes mellitus. Metabolism 55: 852-857.

190. Yamamoto H, Gurney ME (1990) Human platelets contain brain-derived neurotrophic factor. J Neurosci 10: 3469-3478.

191.Lommatzsch M, Schloetcke K, Klotz J, Schuhbaeck K, Zingler D, et al. (2005) Brain-derived neurotrophic factor in platelets and airflow limitation in asthma. Am J Respir Crit Care Med 171: 115-120.
This article was originally published in a special issue, Diabetes \& Exercise handled by Editor(s). Dr. Lisa Stehno-Bittel, University of Kansas Medica Center, USA 